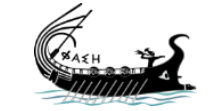

journal.phaselis.org
PHAS LLIS

Issue VI (2020)
Disiplinlerarası Akdeniz Araştırmaları Dergisi

Journal of Interdisciplinary Mediterranean Studies

\title{
Phaselis Büyük Hamam, Hellenistik Tapınak ve Diğer Hamamlarda Kullanılan Yapı Taşları ve Phaselis Yapı Taşı Ocağı
}

\author{
The Cut-Stones of Phaselis Used in Large Bath, \\ Hellenistic Temple and Other Baths and Phaselis' \\ Cut-Stone Quarry
}

\author{
Ferda ÖNER \\ (D) https://orcid.org/0000-0002-9278-6164
}

The entire contents of this journal, Phaselis: Journal of Interdisciplinary Mediterranean Studies, is open to users and it is an 'open access' journal. Users are able to read the full texts, to download, to copy, print and distribute without obtaining the permission of the editor and author(s). However, all references to the articles published in the e-journal Phaselis are to indicate through reference the source of the citation from this journal.

Phaselis: Journal of Interdisciplinary Mediterranean Studies is a peer-reviewed journal and the articles which have had their peer reviewing process completed will be published on the web-site (journal.phaselis.org) in the year of the journal's issue (e.g. Issue IV: JanuaryDecember 2018). At the end of December 2018 the year's issue is completed and Issue V: January-December 2019 will begin.

Responsibility for the articles published in this journal remains with the authors.

c) (1) (-) This work is licensed under a Creative Commons Attribution-

Con NC SA Nommercial-ShareAlike 4.0 International License.

Citation F. Öner, "Phaselis Büyük Hamam, Hellenistik Tapınak ve Diğer Hamamlarda Kullanılan Yapı Taşları ve Phaselis Yapı Taşı Ocağı". Phaselis VI (2020) 13-28.

http://dx.doi.org/10.18367/Pha.20002

Received Date: 23.01.2020 | Acceptance Date: 14.02.2020

Online Publication Date: 06.04.2020

Editing Phaselis Research Project

www.phaselis.org 


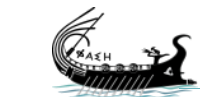

\title{
Phaselis Büyük Hamam, Hellenistik Tapınak ve Diğer Hamamlarda Kullanılan Yapı Taşları ve Phaselis Yapı Taşı Ocağı
}

\author{
The Cut-Stones of Phaselis Used in Large Bath, Hellenistic Temple and Other Baths \\ and Phaselis' Cut-Stone Quarry
}

\author{
Ferda ÖNER*
}

Öz: Phaselis Antalya'nın yaklaşık 55 km güneybatısında yer alan bir ören yeridir. Kentin yapılarında yapı taşı olarak traverten breşi kullanılmıştır. Bu breşleri oluşturan taneler Jura yaşılı kireçtaşlarının (Tekedağı formasyonu kireçtaşları) yamaç molozu olarak birikmiş yığışımlardan oluşmuştur. Kentin Büyük Hamam, Hellenistik Tapınak ve hamam yapılarında da ana malzeme olarak traverten breşlerinden düzgün olarak kesilmiş bloklar kullanılmıştır. Geç Antikçağ'da kentin depremler nedeniyle onarımlar veya yeniden yapılan duvar ve binalarda ise ilksel bloklar ve bunların kırıımış parçaları ve çevreden bulunmuş her türlü moloz kullanılmıştır. Bu taşlar genellikle kumtaşları (kalkarenitik), çört, serpantin, gabro ve bazalt olarak belirlenmiştir. Bu kayaçlar içinde jeolojik olarak bu bölgede rastlanmayan kuvarsit ve şistlerin bulunması ilginçtir. Ayrıca genellikle çatı kaplaması olarak kullanılan kayraklara rastlanması da bunların limanlararası ticaret yoluyla getirilme olasılığını düşündürmektedir. Hellensitik tapınakta yapılan kazılar sırasında ortaya çıkarılan sütunlarda gözlenen fosillerden, bu sütunların olası olarak Üst Kretase yaşlı neritik kireçtaşlarından üretildiği gözlenmiştir. Bu tür oluşumlar bölgeye en yakın Finike yöresindeki Limyra kireçtaşlarıdır. Phaselis kentinin ana yapı malzemesi olan traverten breşlerinin üretildiği ocak alanı şehrin Hellenistik akropolis ile Antalya-Kumluca Otoyolu'nun güneyindeki alan olarak belirlenmiştir. Bu alanda yapı taşının üretildiği ocak aynaları gözlenmiştir. Doğu Nekropolis alanındaki anıt mezarda kullanılan traverten breşlerinin yanı sıra yapay olarak üretildiği kanısına varılan bazı sütunlar da belirlenmiştir.

Anahtar sözcükler: Phaselis, Yapı Taşları, Breş, Limyra, Mermer, Bozuşma, Ocak Yeri, Yapay Sütun

\begin{abstract}
Phaselis is a historical site located about $55 \mathrm{~km}$ southwest of Antalya. Travertine breccia was used as the building stone in the city buildings. The grains forming these breccias are composed of accumulated deposits as slope debris of Jurassic limestones (Tekedağı formation limestones). In the large baths, Hellenistic temple and bath structures of the city, blocks cut properly from travertine breccias were used as the main material. In the Late Antiquity, the city was repaired due to earthquakes or rebuilt walls and buildings, while the primary blocks and their broken pieces and all kinds of debris found from the environment were used. These stones are generally sandstones (calcarenitic), chert, serpentine, gabbro and basalt. Interestingly, these rocks contain quartzites and schists that are not geologically encountered in this region. In addition, the presence of slate, which is generally used as roofing, suggests the possibility of bringing it through inter-port trade. It was observed that these columns were probably produced from Upper Cretaceous neritic limestones. Such formations are Limyra limestones in the Finike region closest to the region. The quarry area where travertine breccias, the main building material of Phaselis was produced, was determined as the area to the south of the Antalya-Kumluca motorway and the Hellenistic acropolis of the city. Quarry pit benches in which the building stone was produced were observed in this area. In addition to the travertine breccias used in the monumental tomb in the East Necropolis, some columns were found to be artificially produced.
\end{abstract}

Keywords: Phaselis, Cut-Stones, Breccia, Limyra, Marble, Alteration, Quarry location, Artifical columns

* Jeoloji Yük. Müh., Competent Person (CP-Australia JORC), PhD., Hacettepe Üniversitesi, Fen Bilimleri Enstitüsü, Jeoloji Bölümü, Ankara. ferdaoner@hotmail.com | @ https://orcid.org/0000-0002-9278-6164 


\section{Giriş}

Phaselis antik kenti çalışmalarına 2019 yılında da devam edilmiştir. Yapılan yüzey araştırmalarında Büyük Hamam ve diğer hamamlar, Tapınak ve çevrelerindeki yapılarda kullanılan taşlar ve bunların özellikleri çalısııımıştır (Fig. 1).

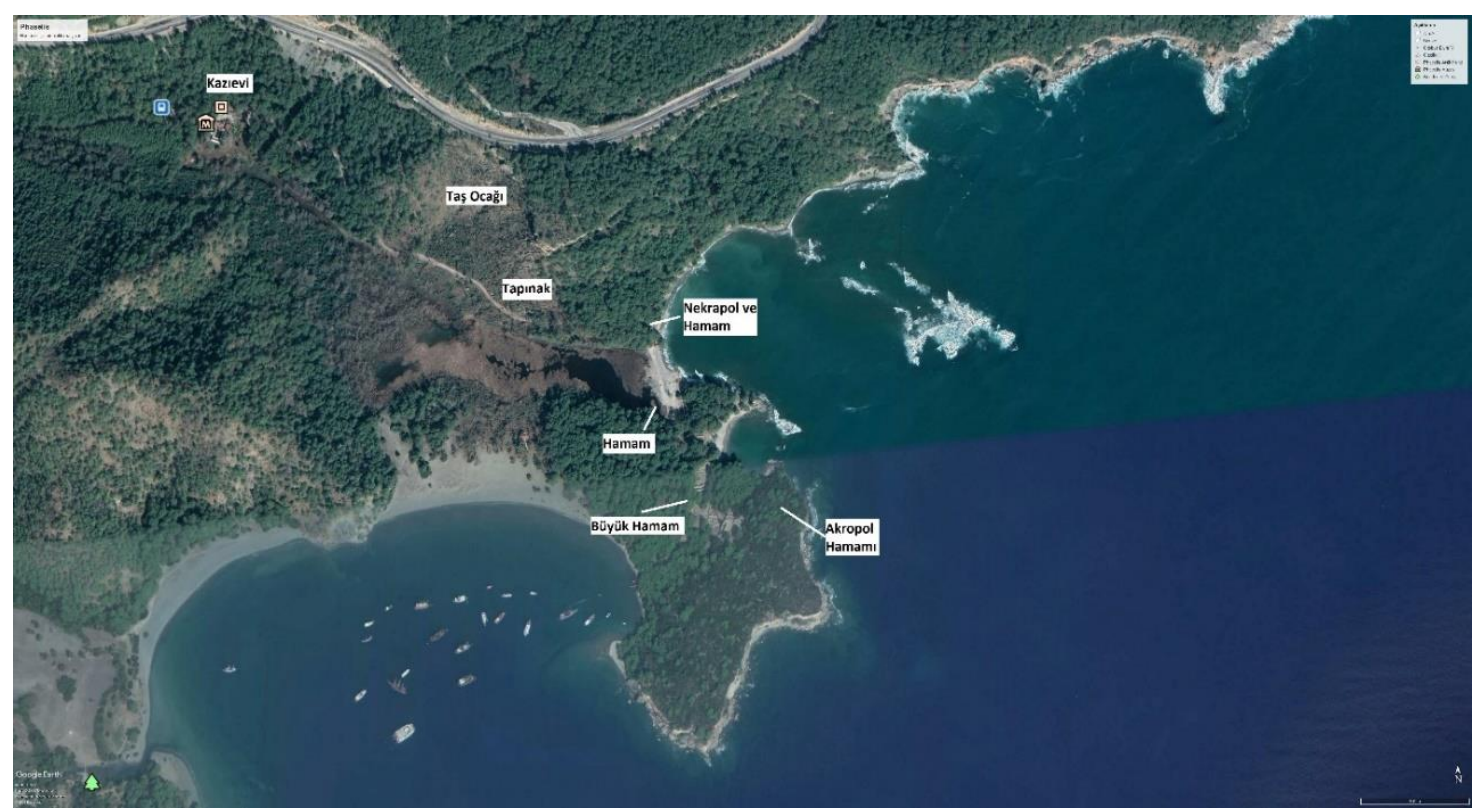

Fig. 1. Phaselis Antik Kenti, Çalışılan Yapılar

Büyük Hamam ve çevresinde ana malzeme olarak düzgün traverten blokları kullanımı gözlenirken diğer hamamlarda genellikle kırık blok parçaları ve çevreden bulunan her türlü taş kullanılmıştır. Hellenistik Tapınak olarak adlandıılan yapının podyumunda düzgün bloklar kullanılmışır. Burada yapılan kazılarda bulunan sütun tamburlarında belirlenen makro fosillerden bu taşların Phaselis'e dışarıdan getirildiği sonucu ortaya çıkmıştır.

\section{Yapılar}

\subsection{Büyük Hamam Yapı Taşları}

Büyük Hamam'da ana yapı taşı olarak traverten breşleri kullanılmıştır (Fig. 2) ${ }^{1}$. Phaselis antik kentinin genelinde olduğu gibi ana yapı taşları traverten breşleridir. Büyük Hamam 14 nolu mekanının (duvarlarında, Fig. 2'de görüldüğü gibi " $A$ " duvardaki traverten breşleri düzgün kesilmiş bloklar halinde ve düzenli olarak örülmüştür. " $A$ " duvarında bloklar arasında eklektik taş yada şipolyen malzeme kullanılmamıştır. "B" duvarında ise altta ve sağ tarafta büyük bloklarda inşa edilmesine rağmen bunların aralarında eski duvarlardan alınan traverten breş blok parçaları sipolyen malzeme olarak kullanılmıştır. Aynı duvarın orta- üst kesimlerinde ise tamamen eklektik taşlar kullanılmış ve taşların çoğunluğu yuvarlak köşelidir.

Hamamın 14 nolu mekanının kuzey duvarında ise iri kesilmiş traverten breş blokları gözlenmekle birlikte yapı taşlarının dizilimi çok düzensizdir (Fig. 3). Aynı zamanda büyük taşlar arasında gelişigüzel farklı kaynaklardan gelen taşların ikincil kullanımı göze çarpmaktadır.

1 Öner 2018. 


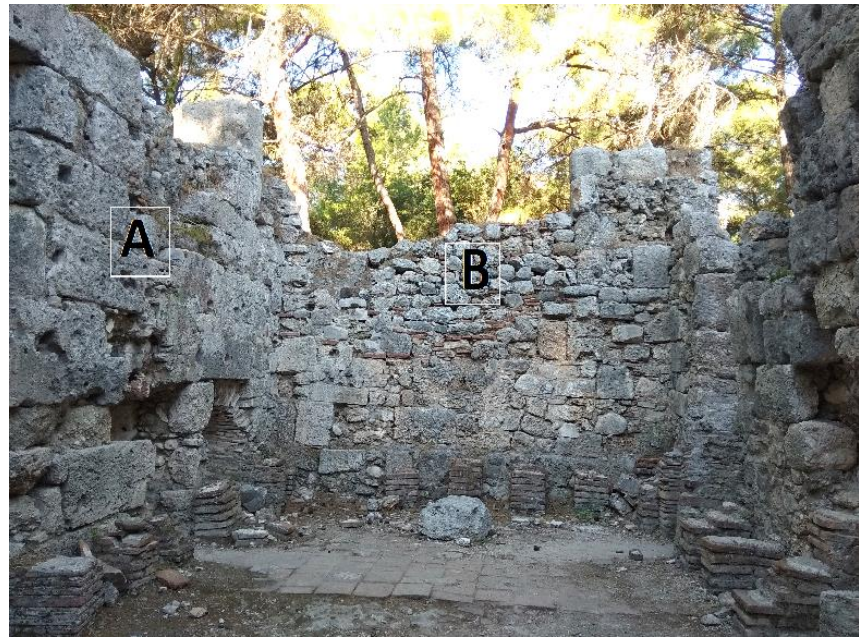

Fig. 2. Büyük Hamam 14 Nolu Mekan Yapı taşları

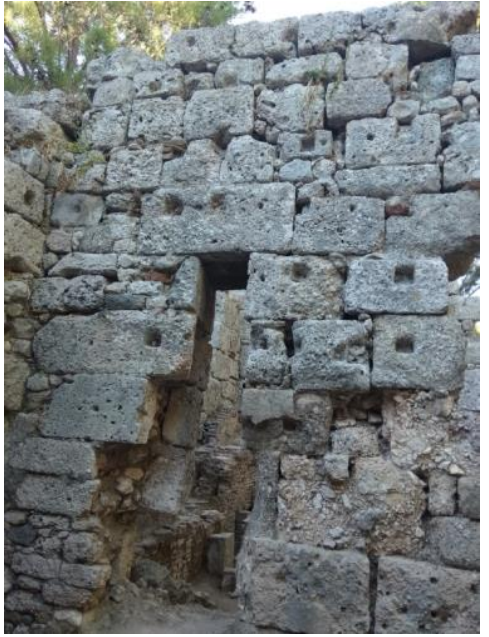

Fig. 3. Büyük Hamam 14 Nolu Mekanının Kuzey Duvarı

Yapının hemen her yerinde eski bloklar ve taşlar düzeltilmeden gelişigüzel kullanılması ile arada kalan boşluklar küçük taşlarla doldurulmaya çalışılmıştır (Fig. 3). Bu yapıda diğerlerine göre daha fazla traverten bloklar kullanıldığı dikkat çekmektedir (Fig. 4)². Bu bloklar düzgün ve yaklaşık $50 \mathrm{~cm}$ den fazla uzunluklara sahiptir.

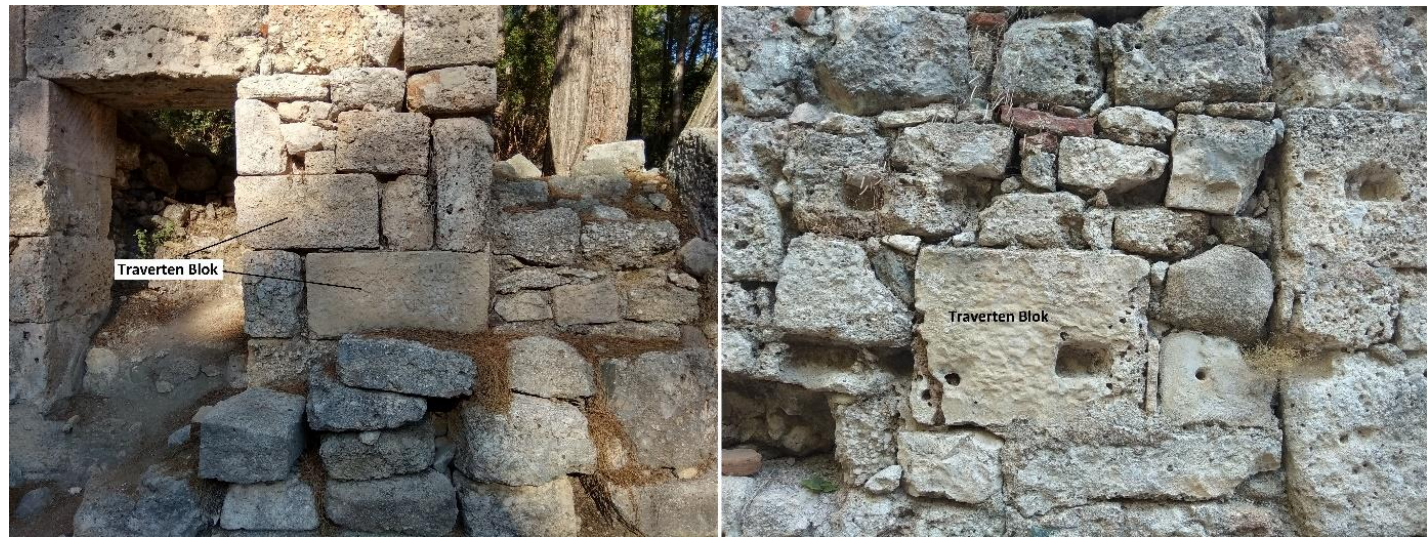

Fig. 4. Büyük Hamam'da Kullanılan Traverten Bloklar

Duvarlarda kullanılmış traverten bloklarında değişik aşınma ve bozunmalar tespit edilmiştir (Fig. 5). Öner (2018) bu alterasyonları traverten breşlerini bağlayan matriks çimentoya bağlamıştır. Karbonat çimentolularda aşınma çok azken kil matriksli olanlarda aşınma çok fazla olmaktadır.

Blokların üzerine mermer plakaları yapıştırmak için harçlarda kireç bağlayıcının yanında çok ince (en fazla $1 \mathrm{~mm}$ ) bazalt serpantin ve tuğla kiremit tozu bulunan kum malzeme kullanılmıştır (Fig. 6).

Büyük Hamam duvarlarında aralarında harç olmayan (serbest durumda) bazı Limyra bloklarına da rastlanmıştır (Fig. 7). Bunlar alanda yakın geçmişte yapılmış (Antalya Müzesi başkanlığında 1990'lı yıllarda yapılan temizlik ve düzenleme çalışmaları) düzenlemelerle bağlantılı olabilir.

2 Öner 2018. 


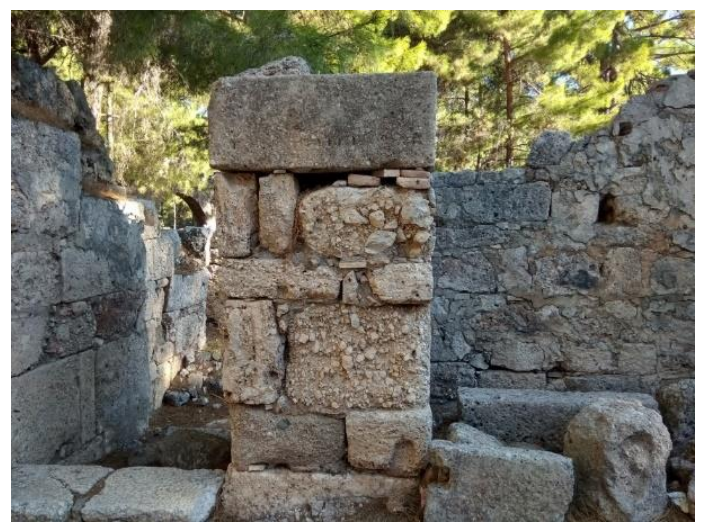

Fig. 5. Bloklarda Görülen Farklı Düzeydeki Bozunmalar

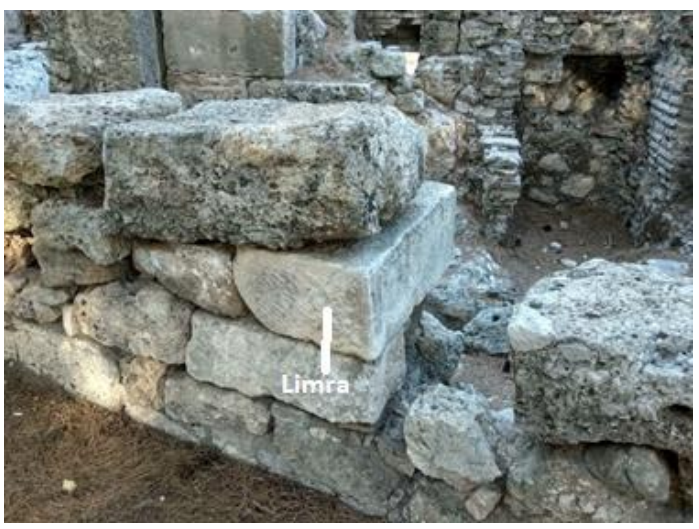

Fig. 7. Limyra Bloklar

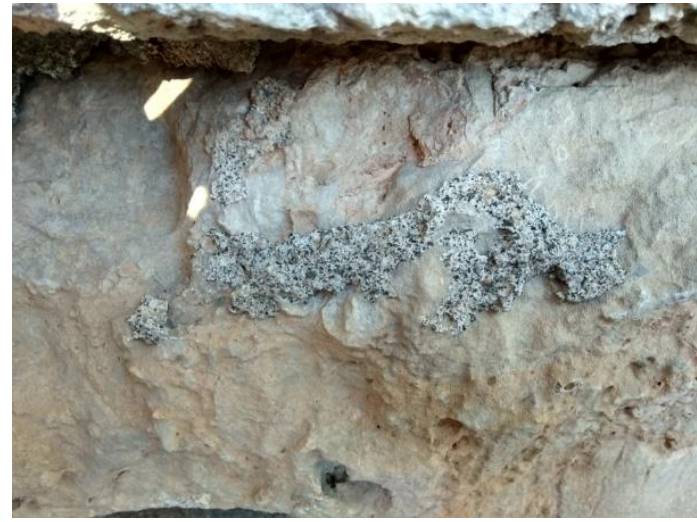

Fig. 6. Blok Üzerlerindeki Harçlar(Siyah taneler bazalt ve serpantin)

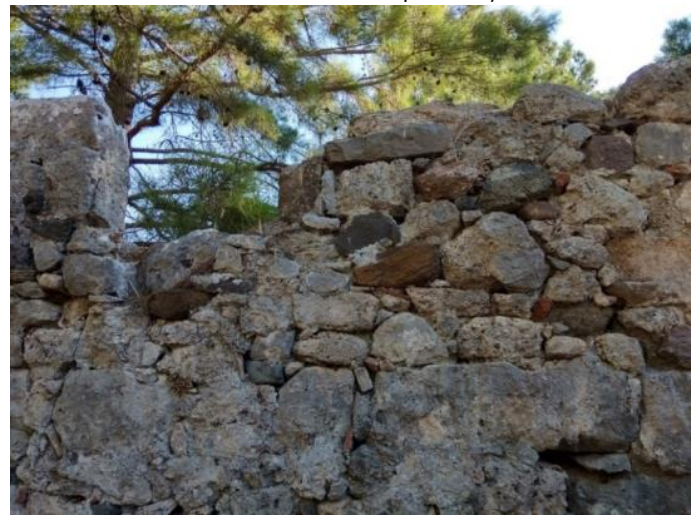

Fig. 8. Büyük Hamam Duvarlarında Kullanılan Bazalt ve Serpantinler

Düzensiz olarak örülen duvarlarda diğer yapılarda olduğu gibi Phaselis çevresinden olmakla birlikte erken dönem yapılarda kullanılmayan bazalt ve serpantin bloklarına da rastlanmaktadır (Fig. 8). Fig. 8 ' de görüldüğü gibi koyu renkleriyle kolaylıkla ayırt edilebilen bazalt ve serpantinler en fazla 15-20 $\mathrm{cm}$ boyutlarında kısmen yuvarlaklaşmış (akarsu faaliyetleri ile yuvarlaklaşma) akarsu çakıl ve bloklarından alınmış izlenimi vermektedir.

Küçük Hamam ve latrinada kullanılmamış bazalt taşları da Büyük Hamam'da da tespit edilmiştir. Büyük Hamam'da gözlenen porfiri dokulu bazalta (andezit?) bölgede pek rastlanmaması nedeniyle ilgi çekicidir (Fig. 9). Bunun kaynağının araştırılması jeolojik açıdan önem arz etmektedir. Ayrıca kayaç köşeli bir yapıya sahip olduğundan akarsu malzemesi değildir. Yakın bir yerden kırılarak alınmış izlenimi uyandırmaktadır.

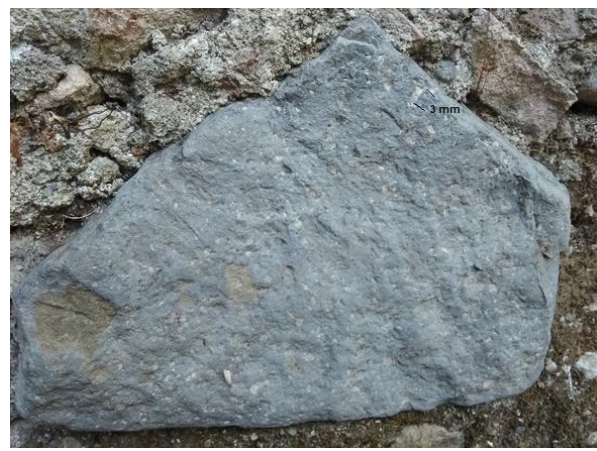

Fig. 9. Büyük Hamam Duvarında Kullanılmış Porfiri Kayaç

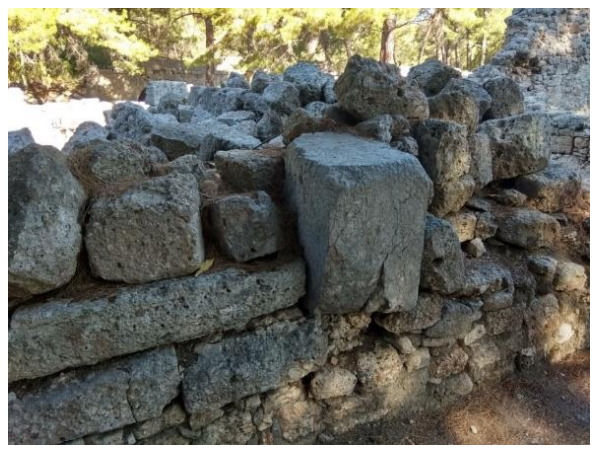

Fig. 10. Büyük Hamam Dış Duvarında Kullanılan Jura Yaşlı Kireçtaşı Bloğu 
Bu dönemde Tahtalıdağ formasyonuna ait Jura kireçtaşları ise kesilmiş taş olarak kullanılmıştır. Bu taşların blok yerine genellikle sütun veya sütun başı formunda kesildiği gözlenmiştir (Fig. 10).

\subsection{Agora}

Traverten breşleri genelde blok şeklinde yapılarda kullanılmıştır (Fig. 11). Bununla birlikte az da olsa agorada yapının dışında serbest halde ve Büyük Hamam önündeki yolda sütun şeklinde kesilmiş traverten breşlerine rastlanmıştır (Fig. 12).

Agora içinde bulunan serbest haldeki yanyana konulmuş traverten breşinden yapılmış iki sütunun soldaki tam olarak silindir olarak yapılmışken sağdaki ise daha oval bırakılmıştır. Alt kesimi düzdür (Fig. 13).

Fig. 14'de Phaselis'in traverten breşinden yapılmış sütun ile Limyra taşından yapılmış sütun tamburları kentin ana caddesi üzerindeki revağın kaldırımında yan yana görülmektedir. Genellikle traverten breşlerinden yapılmış sütunlar daha ince kesilmiştir.

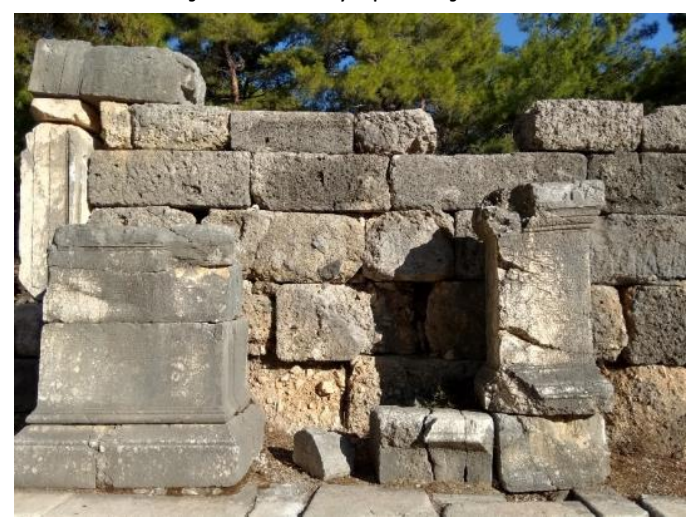

Fig. 11. Hadrianus Tetragonal Agoranın Ön Cephesi

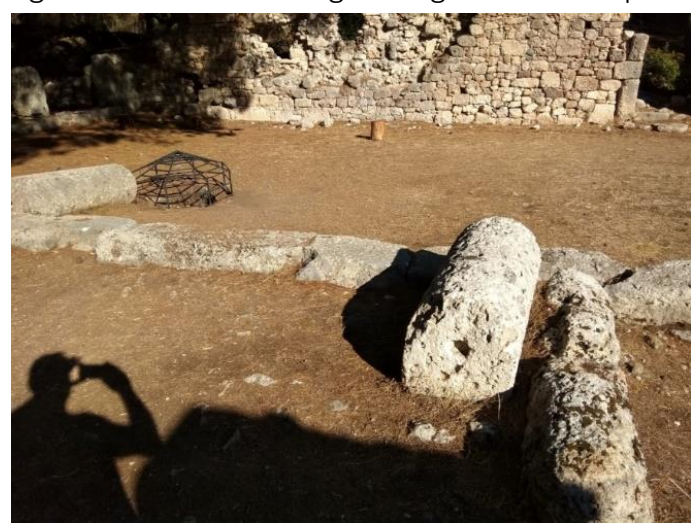

Fig. 13. Agora İçinde Serbest Halde Duran Sütunlar

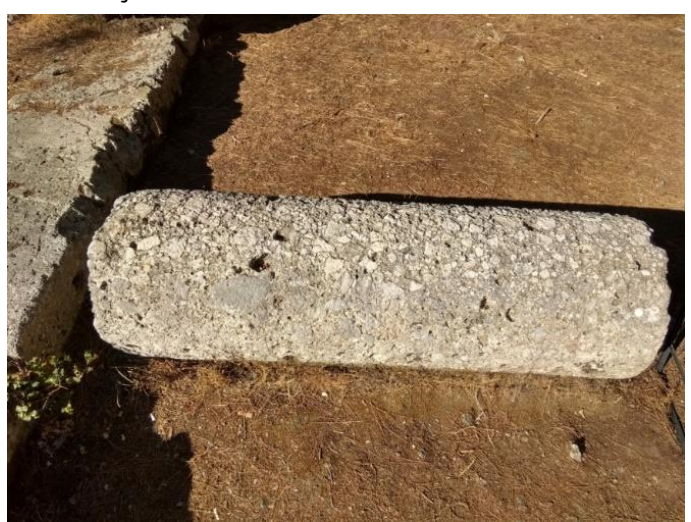

Fig. 12. Agora İçinde Serbest Duran Sütun

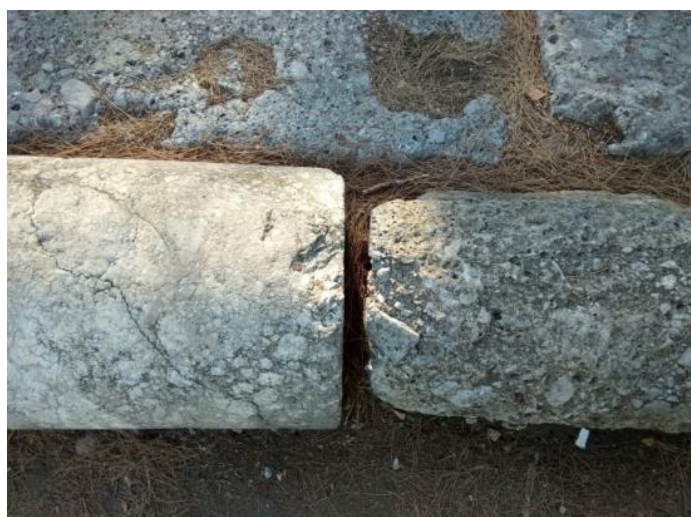

Fig. 14. Limyra Breşi (Solda) ve Traverten Breşi (Sağda) Sütunlar

Limyra ve traverten breşleri şekilde de görüldüğü gibi kolaylıkla ayırt edilebilmektedir (Fig. 14). Limyra breş parçaları Limyra mermerinin beyaz-bej rengi ve daha sıkı dokulu olmasıyla ayırt edilmektedir. Traverten breşlerinde ise Jura kireçtaşlarının tipik gri-bej rengi görülmekte ve matriksin erimesi nedeniyle yüzey bozunmaları aşırıdır.

\subsection{Hellenistik Tapınak}

Phaselis Araştırma İstasyonu'ndan Kuzey Limanı'na gelişte sol tarafta bir podyum göze çarpmaktadır. Önceki araştırıcılar buranın Dor düzeninde bir tapınak olduğunu belirlemişlerdir (Arslan - Tüner 
Önen 2019, 426 vd.). Podyumun taşları Phaselis'in hemen tüm yapılarının temellerinde bulunan traverten breşlerinden kesilmiş dikdörtgenler prizması şeklinde genelde $50 \mathrm{~cm}$ den uzun bloklar şeklindedir. Buradaki taşların düzgünlüğü ve taş örmesindeki iş̧̧ilik tapınağın yapımına özen gösterildiğini göstermektedir (Fig. 15).

Hellenistik Tapınağın podyumunun üstünde pronaos ve naos bölümlerinde kesiminde başlayan kazılar sırasında insitu durumdaki sütun tamburları ortaya çıkarılmıştır (Fig. 15 ve 16). Bu sütunlar eklektik taşlardan yapılmışlardır. Şu ana kadar

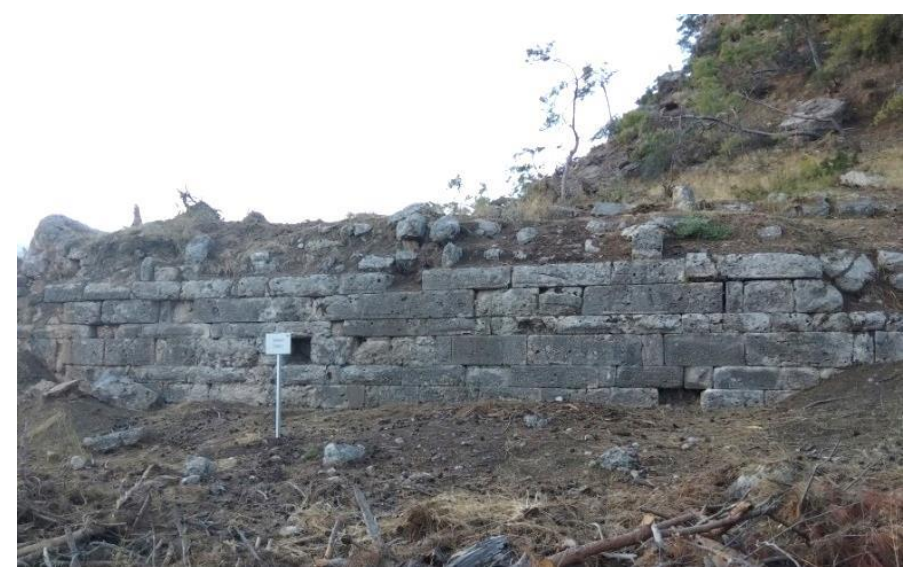

Fig. 15. Tapınağın Podyumunda Kullanılan Traverten Breş Bloklar çıkarılan sütun tamburlarının üst kesimleri oldukça bozunduğu için gri bir renk almıştır (Fig. 16). İlk başta Tahtalıdağ formasyonuna ait Jura yaşlı kireçtaşları olabileceğini düşündürmektedir.
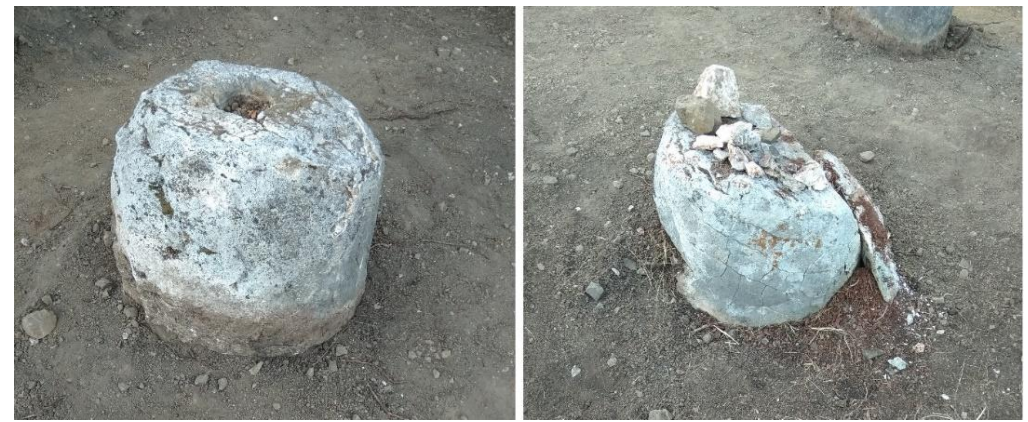

Fig. 16. Tapınak Sütunları (Kireçtaşı)

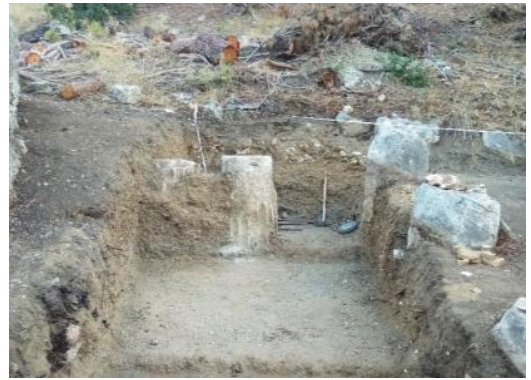

Fig. 17. Tapınak Kazısında Ortaya Çıkan Sütunlar

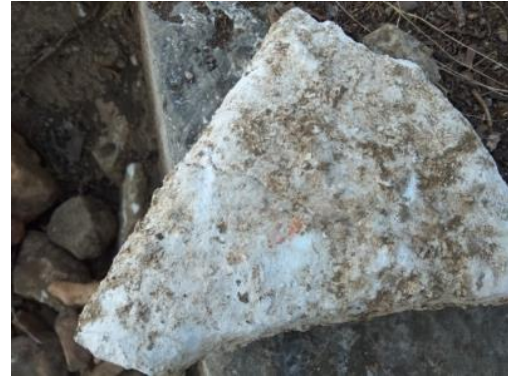

Fig. 18. Sütun Parçası Fosilli Neritik Kireçtaşı

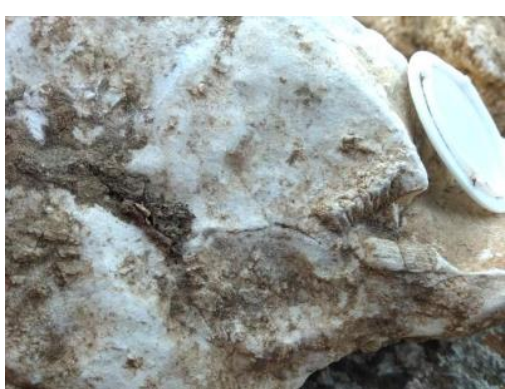

Fig. 19. Sütunların Kırık Yüzeylerinde Gözlenen Mercan (Coral) Fosilleri

Fig. 16'dan da görüldüğü gibi oksidasyondan daha az etkilenmiş sütunlar beyaz renklidir. Kazı ilerledikçe alt zonlarda ise bu beyaz renk ve ince taneli neritik kireçtaşı özelliği daha belirginleşmiştir (Fig. 17). Bu kireçtaşları üzerinde bazı fosil kavkılarına rastlanmaktadır (Fig. 18). Kazının alt seviyelerinde çıkan sütunlarda bu fosiller daha belirginleşmiştir (Fig. 19).

Yapılan ön incelemeler bu fosillerin Parasmilia veya Trochosmilia (Kretase yaş) cinsi mercanlara çok benzediğini göstermiştir (Fig. 20). Bu tür fosillerin Kretase yaşlı Finike Limyra kireçtaşlarında görüldüğü bilinmektedir ${ }^{3}$.

3 Erol 2008; Moore et al. 1952. 

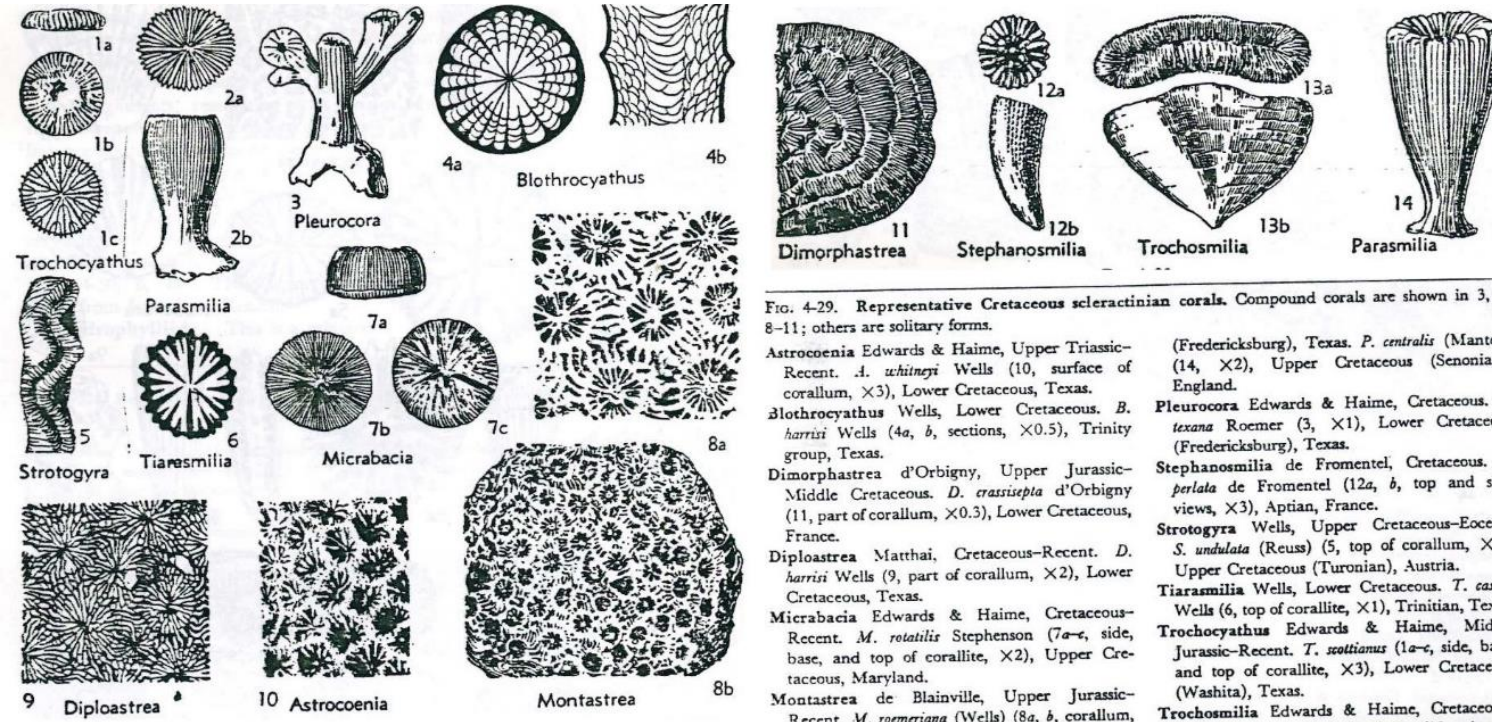

rals are shown in 3,5 , $8-11$; others are solitary forms. $\begin{array}{ll}\text { Astrocoenia Edwards \& Haime, Upper Triassic- } & \text { (Fredericksburg), Texas. P. centralis (Mantell) } \\ \text { Recent. A. whitnegi Wells (10, surface of } & (14, \times 2) \text {, Upper Cretaceous (Senonian) }\end{array}$ (lochrocyathus Wells, Lower Cretaceous. ( (Fredericksburg), Texas

Dimorphastrea d'Orbigny, Upper Jurassic- Stephanosmilia de Fromentel, Cretaceous. $S$. Middle Cretaceous. $D$. crassisepta d'Orbigny perlata de Fromentel (12a, b, top and side (11, part of corallum, $\times 0.3$ ), Lower Cretaceous, views, $X 3$ ), Aptian, France

France. Strotogyra Wells, Upper Cretaceous-Eocene Diploastrea Matthai, Cretaceous-Recent. D. S. undulata (Reuss) (S, top of corallum, $X$ 1), harrisi Wells (9, part of corallum, $\times 2$ ), Lower Cretaceous, Texas. Micrabacia Edwards \& Haime, Cretaceous-
Recent. M. rotatilis Stephenson (7a-c, side, base, and top of corallite, $\times 2$ ), Upper Cretaceous, Maryland.

Montastrea de Blainville, Upper JurassicRecent. M. roemeriana (Wells) $(8 a, b$, corallum, X3, X1), Lower Cretaceous, Texas.

Parasmilia Edivaras \& Haime, Lower Cretaceous-Recent. P. austinensis Roemer (2a, b top and side views, $\times 1$ ), Lower Cretaceous

$S$. undulata (Reuss) (5, top of corallum, $\times 1)$ iarasmilia Wells, Lower Cretaceous. T. castei Wells (6, top of corallite, $X 1)$, Trinitian, Texad Jurassic-Recent. T. scottianus (1a-c, side, base, and top of corallite, $\times 3$ ), Lower Cretaceous (Washita), Texas.

rochosmilia Edwards \& Haime, CretaceousMiocene. T. didymophyla Felix (13a, b, top and side views of corallite, $X 0.7)$, Upper Cieacrous (Turonian), Austria.

Fig. 20. Mercan Fosilleri (Moore 1952)

Bu tür mikro boşluklu kireçtaşlarının iç renkleri diğer taşlara göre çok daha beyaz renktedir (Fig. 19). Aynı kireçtaşı parçaları içeren breş bloklarına da rastlanmıştır. Fakat bunların herhangi bir kenar köşesi olmadığından yapı taşı olup olmadığına karar verilememiştir. Bu kayaçların Jura'dan daha genç Üst Kretase yaşlı Limyra kireçtaşlarının fosilli seviyesi olma ihtimali yüksektir (Erol 2008).

Daha önce Phaselis Küçük Hamam ve latrinasında belirlenen traverten bloklarına (Öner 2018) Hellenistik tapınak kaidesinin üst kesiminde görülmüştür (Fig. 21).

Yaklaşık 20×35×100 cm boyutlarındaki bu blok çok düzgün kesilmiştir (Fig. 21).

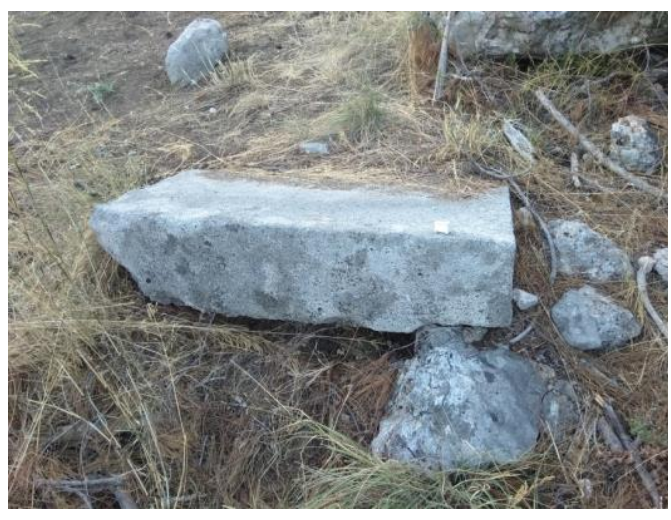

Fig. 21. Tapınak Bölgesinde Gözlenen Serbest Traverten Blok

\subsection{Akropolis ve Hamam}

Akropolis'teki yapılarda ana malzeme traverten breşi olmakla birlikte (Fig. 22), son dönemlerde yapılan eklemeler ve tamiratlarda dere çakıl ve bloklarından eski yapı malzemesi parçalarına kadar birçok taş kullanılmıştır.

Konut olarak kullanıldığı düşünülen binanın kemerinde kullanılan taşlar Jura kireçtaşı olarak Tahtalıdağ kireçtaşlarından kullanılmıştır (Fig. 23).

Akropolis'te gezilen kısımdaki yapılarda görülmemekle birlikte bölgeye ait olmayan bazı taşlar da görülmüştür. Bunlardan yaklaşık $20 \mathrm{~cm}$ büyüklüğünde bir yeşil şist parçası görülmüştür (Fig. 24). Bölgede bu tür bir kayaç içeren bir formasyon bilinmemektedir ${ }^{4}$.

4 Şenel et al. 1981. 


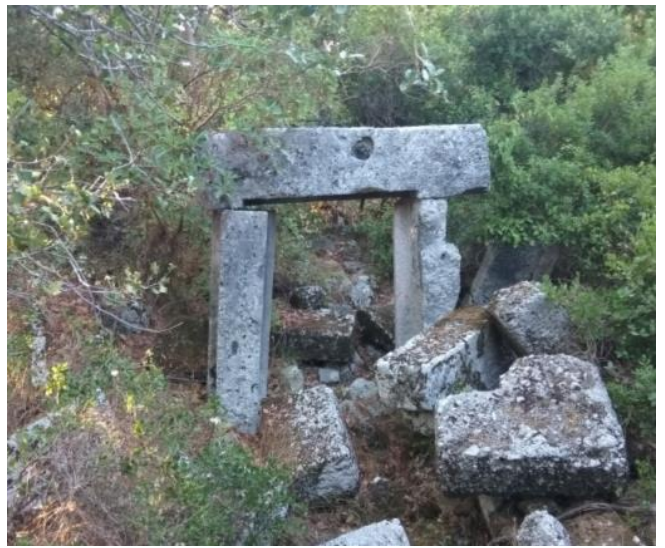

Fig. 22. Akropolis, Tiyatro Yakınlarında Kapı (Bloklar Traverten Breşlerinden Kesilmiştir)

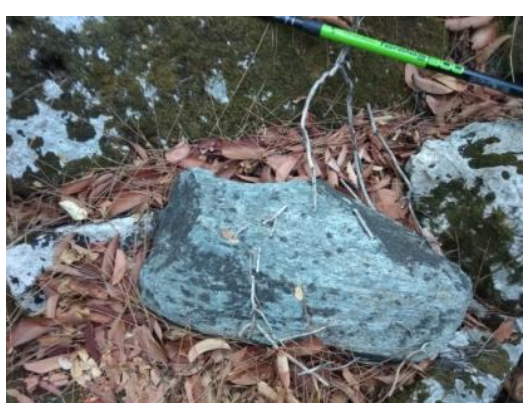

Fig. 24. Akropolis'te Serbest Halde Duran Yeşil Şist Blok Parçası

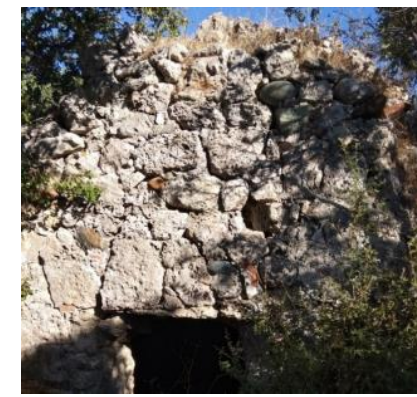

Fig. 25. Akropolis Hamamı Güneydoğu Dış Cephe Duvarı

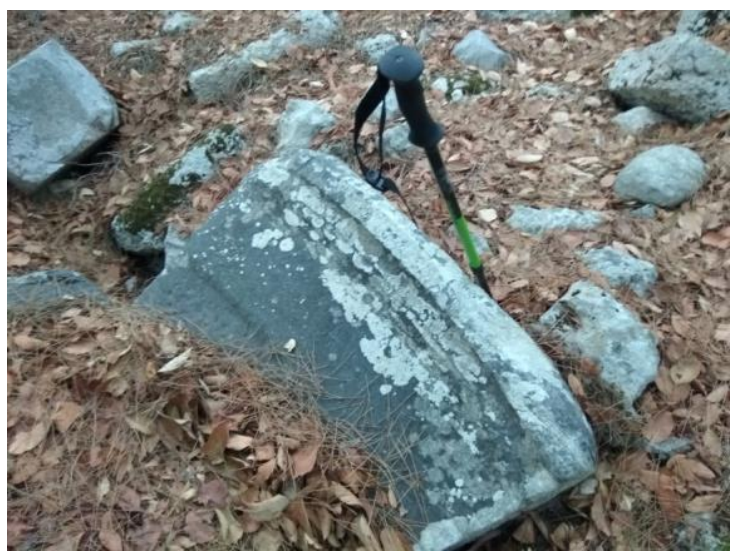

Fig. 23. Konut Binası Kemerinde Kullanılan Jura Yaşlı Kireçtaşları

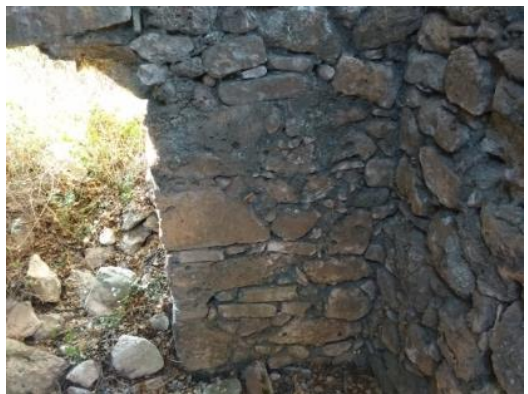

Fig. 26. Akropolis Hamamı Giriş Duvarında Kullanılan Kalkarenitler (Kahve-Pembe Renkli Taşlar)

Akropolis'te tiyatronun yaklaşık 90 m güneydoğusunda 2017 yılı disiplinler arası Phaselis yüzey araştırmaları sırasında akropolis ekibi tarafından tespit edilen küçük hamam yapısında genelde düzgün olmayan kayaç parçaları kullanılmıştır (Fig. 25). Phaselis'in ilk yapılarında görülen ve en azından temel veya bina alt kesimlerinde gözlenen düzgün kesilmiş traverten breşlerine bu binada rastlanmamıştır (Fig. 25).

Binada çok miktarda Kretase yaşlı filiş birimine ait kumtaşları da kullanılmıştır (Fig. 26). Kalkarenit olarak tanımlanan karbonatlı kumtaşları binanın büyük çoğunluğunda kullanılmıştır ${ }^{5}$. Binada bazı çört ${ }^{6}$ parçalarına da rastlanmıştır (Fig. 27). Bunların kalkarenitlerin ara seviyelerindeki çörtler olabileceği düşünülmektedir.

Hamam iki odalı bir mekan olarak görülmüştür. Iki odayı birbirine bağlayan kapı lentosu çok ilginçtir (Fig. 28). Bu malzeme yapılan görsel incelemede kum malzeme kullanılarak dökülen beton parçası gibi durmaktadır. İleri araştırmalar için örnek alınmasında yarar görülmektedir.

Hamam içinde yerdeki kayaç parçaları içinde yeşil-gri renkli bir taş görülmüştür (Fig. 29). Yaklaşık $10 \times 10 \times 1 \mathrm{~cm}$ boyutlarındaki kayaç yakından incelendiğinde arduvaz/sleyt türü bir kayaç olduğu görülmüştür. Kayrak olarak adlandırılan bu kayaç bölgede bulunmayan bir kayaçtır. Bilindiği gibi kayraklar genelde yer, duvar ve çatı kaplamasında kullanılmaktadır. Bu bölgeye en yakın bu tür kayaçlar ya Menderes Masifi (Muğla ve Denizli) örtü şistleri olarak (Kayrak) adlandırılan metamorfik

Öner 2018, 356.

6 Çört: Genellikle sedimanter ortamlarda çökelen kimyasal amorf silis çökelleridir. Oldukça sert ve sağlam taşlar oluşturur. 
serilerde veya Alanya Masifindeki (Kayrak) şistlerde görülmektedir. Bununla birlikte bu kadar ince yapraklanma verebilen kayraklar Türkiye'de oldukça azdır.

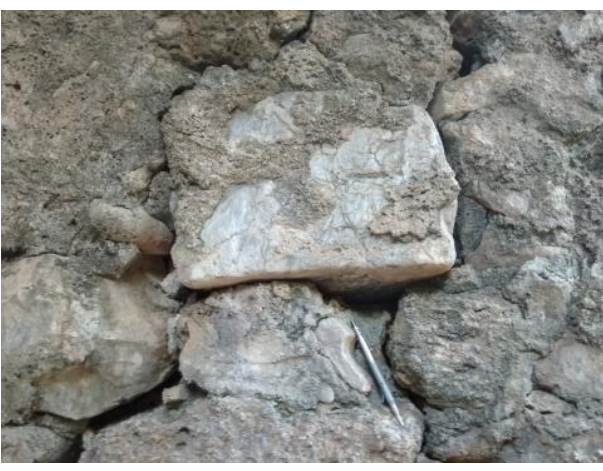

Fig. 27. Akropolis Hamamı Duvarında Kullanılan Çört Blok

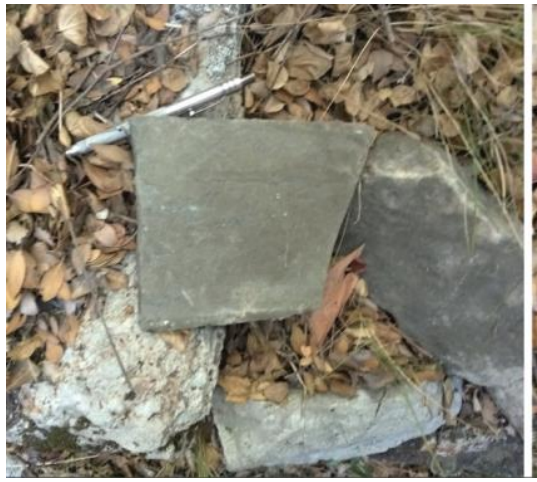

Fig. 29. Akropolis Hamamı'nda Bulunan Kayrak

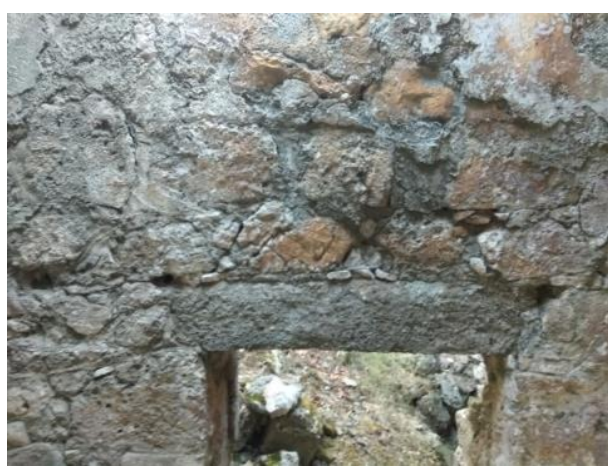

Fig. 28. Akropolis Hamamı Kapı Lentosu

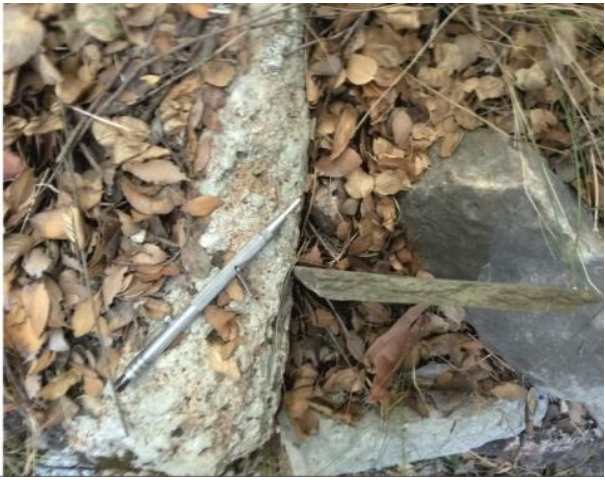

Phaselis'te gözlenen metamorfik kayaçların (şist, arduvaz/Sleyt ve kuvarsit?) kökeni limanlararası ticaret ile gelen malzeme ile olabilir. Şist ve kuvarsitin dere çakılı şeklinde olması çevredeki akarsulardan alınan malzemeden kaynaklanabilir. Bununla birlikte arduvaz/sleyt olarak tanımlanan kayacın çatı veya duvar kaplamasında kullanıldığını düşündürmektedir. Ülkemizde tarihi dönemlerden itibaren Denizli, Muğla yörelerinde genelde duvar ve yer kaplaması olarak kullanılan kayrak taşına Sinop ve Kastamonu yörelerinde çatı kaplaması olarak kullanılmaktadır. Avrupa'da ise özellikle Ingiltere ve Fransa'da çatı kaplaması olarak (Fig. 30 ve 31) çok eski zamanlardan bu yana kullanılmaktadır?

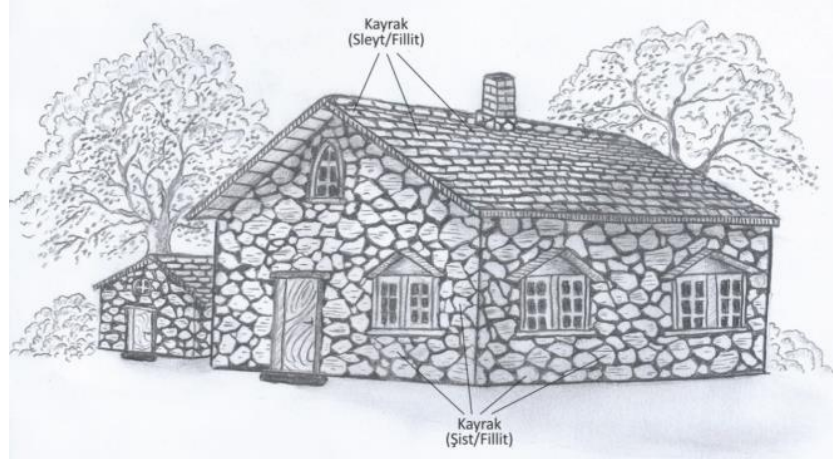

Fig. 30. Binalarda Kayrak Kullanımı kropolis Hamamında Bulunan Kayrak (Işık 2019)

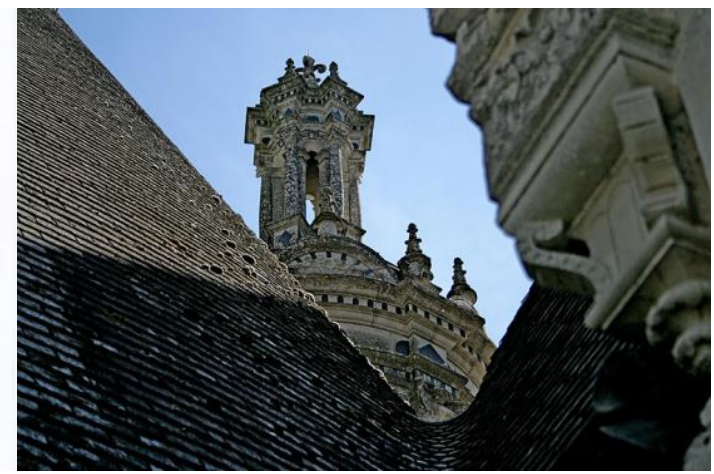

Fig. 31. Kilise Çatısı Kayrak Kullanımı (Işık 2019)

Işık 2019. 


\subsection{Su Kemeri Yanındaki $2 \mathrm{M} 6$ Hamam? Yapısı}

Kuzey limandaki Su Kemeri (Aquaeductus) yanında 2M6 Hamam? olarak tanımlanan yapı da Phaselis'in son dönemlerinde görülen düzensiz duvar örülmesi şeklinde yapılardandır. Bu binada da yuvarlaklaşmış dere çakılları dahil her türlü taş kullanılmıştır (Fig. 32).

Hamam? yapısındaki duvar taşları arasında duvarın şakulünü tutturmak için kullanılan yassı bir taş dikkat çekmiştir. Bu taşın akropolis'te tespit edilen şistin benzeri olduğu görülmüştür (Fig. 33 ).

Bina duvarlarında çok miktarda traverten breşi parçası yanında gabro-bazalt parçaları da kullanılmıştır (Fig. 34).

Hamam? yapısı duvarlarında bazı kuvarsitlere de rastlanmıştır. Kısmen gri beyaz renkli kuvarsit blokları yaklaşık $20 \mathrm{~cm}$ büyüklüktedir (Fig. 35). Kısmen yuvarlaklaşmış bu bloklar akarsu bloğu olarak değerlendirilmiştir.

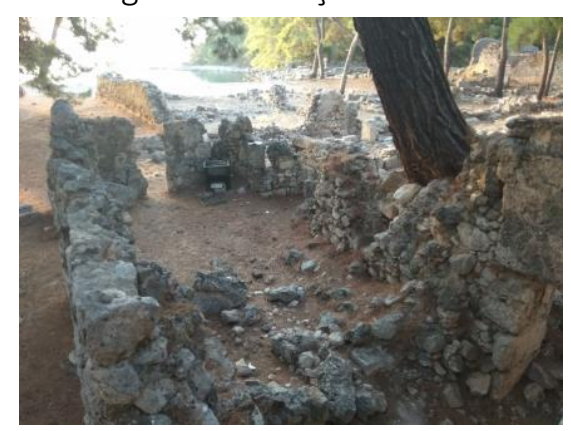

Fig. 32. 2M6 Hamamı? Duvarları

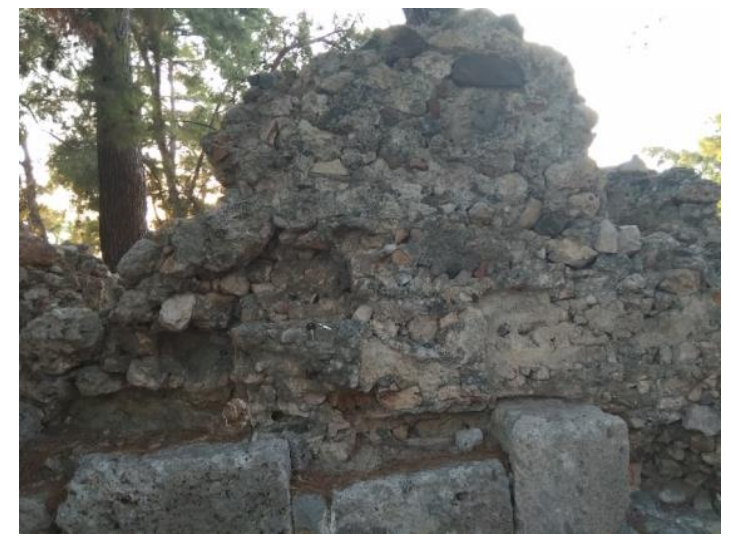

Fig. 34. 2M6 Hamam? Duvarında Kullanılan Serpantin ve Bazaltlar

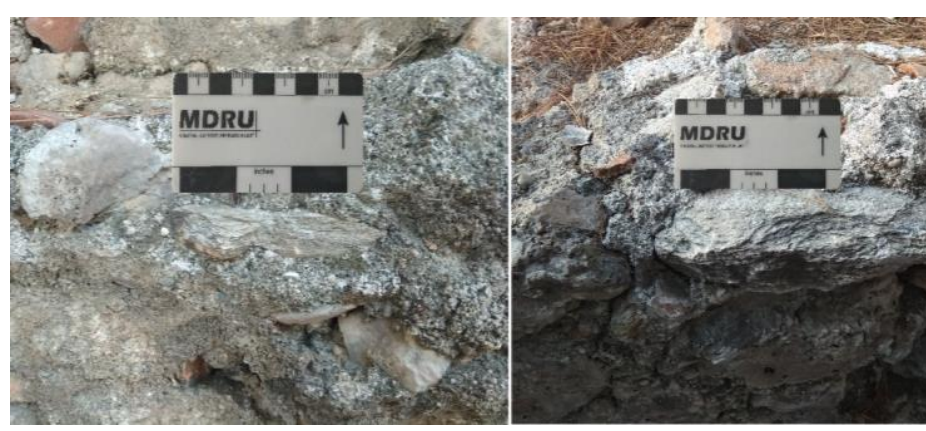

Fig. 33. 2M6 Hamam? Duvarında Kullanılan Şistler

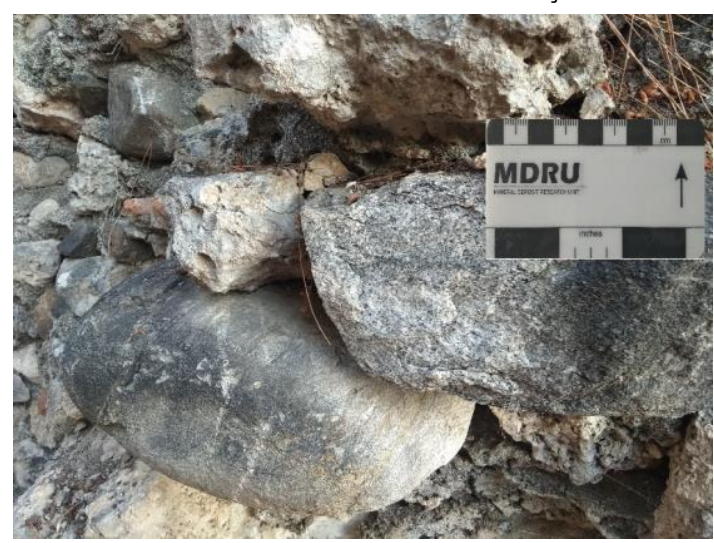

Fig. 35. Nekropolis Hamamı 3H? Duvarında Kullanılan Kuvarsitler

\subsection{Doğu Nekropolis ve Nekropolis Hamamı 3H? Yapısı}

Doğu Nekropolis'in hemen girişinde yer alan hamam yapısı ve nekropolis'in Kuzey Limanı girişindeki anıt mezar yapı taşları incelenmiştir. Hamam yapısı genelde Phaselis'in son dönemlerinde yapılan yapılar gibi devşirme taşlardan yapılmıştır.

Anıt mezarın duvarlarında bariz olarak Phaselis'in ilk yapılarında görülen düzgün ve büyük blok kullanımı ve düzgün işçilikle yapılmış duvarlar görülmektedir. Bu duvarlar traverten breşlerinden kesilmiş bloklarla örülmüştür (Fig. 36). 


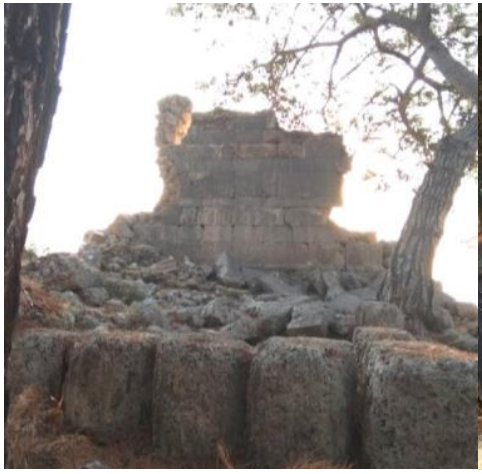

Fig. 36. Anıt Mezar Duvar Kalıntıları

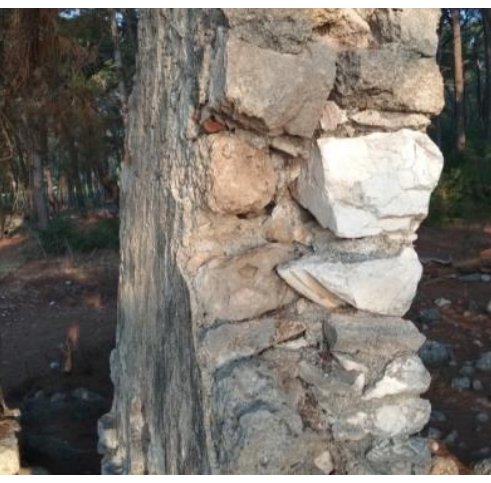

Fig. 37. Anıt Mezar Üst Duvarları Mermer Parçaları

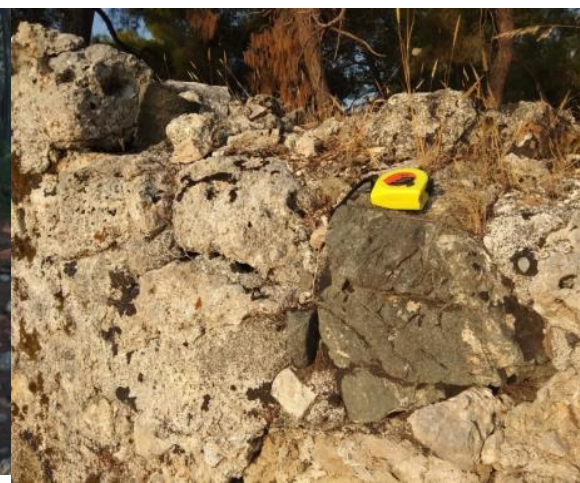

Fig. 38. Serpantin Blok

Bu duvarların temelleri üzerine devşirme malzemeden düzensiz duvarlar yapılmıştır. Duvarlarda Hadrianus Kapısı'ndaki parçalara benzer mermerlerde kullanılarak inşa edilmiştir (Fig. 37).

Yapının moloz duvar örgüsünde serpantin parçalarına da rastlanmaktadır (Fig. 38).

Anıt mezar ve yanındaki hamam yapılarında devşirme malzeme olarak değişik sütun tamburları ve bloklar kullanılmıştır. Illk bakışta traverten breşinden kesilmiş gibi görülen bu bloklar yakından incelendiğinde bunların yapay olarak yapıldığı kanısına varılmıştır (Fig. 39).

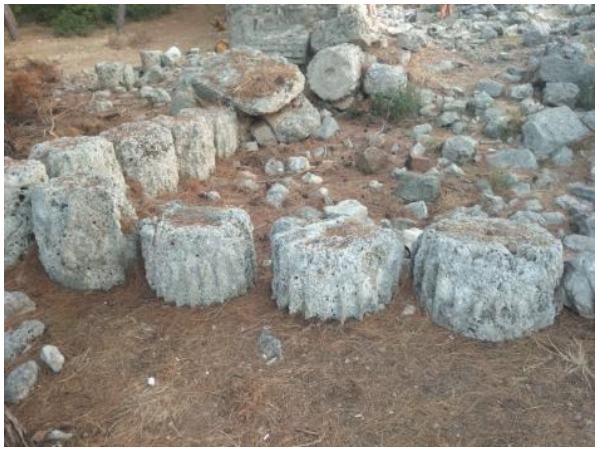

Fig. 39. Anıt Mezar ve Yanındaki Hamamda Kullanılan Sütunlar

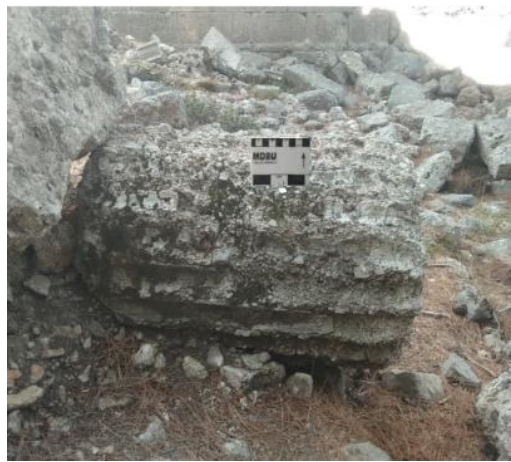

Fig. 42. Anıt Mezar'da Serbest Sütun

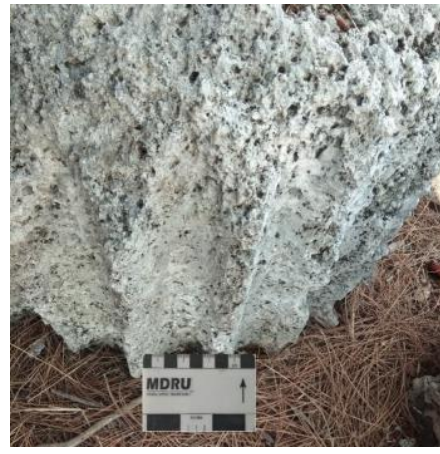

Fig. 40. Anıt Mezar ve Hamam Yapısında Kullanılan Sütunlar

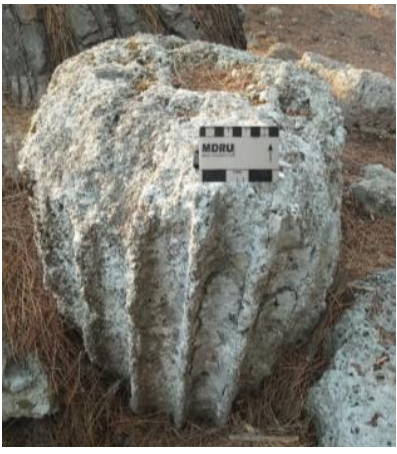

Fig. 41. Sütunlar Üzerine Uygulanan Sıva Düzeltme

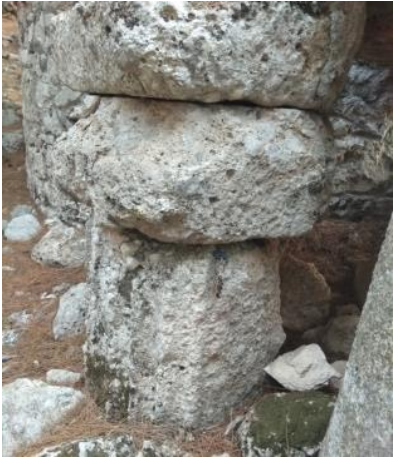

Fig. 43. Akropolis Hamamı Batı Duvarında Üst Üste Sütun Tamburları ve Bloklar

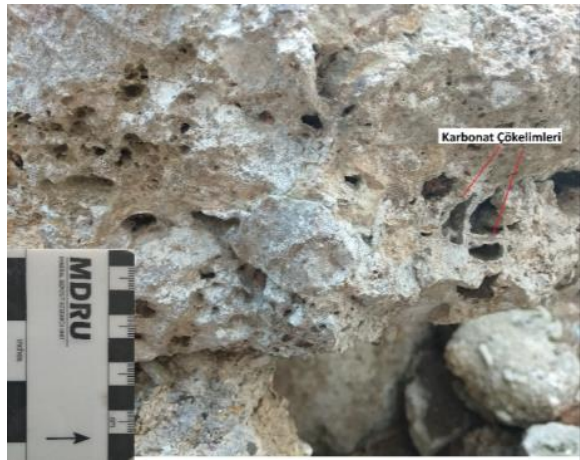

Fig. 44. Traverten Breşlerinde Bağlayıcı Doğal Karbonat Çimento 
Sütun tamburlarının yapısına bakıldığında bir kalıptan çıkmış izlenimi vermektedir (Fig. 40). Fig. 40'a bakıldığında sütun yapımında kullanılan taneler kalıba göre yönlendiği açıkça görülmektedir.

Daha sonradan bu sütun tamburlarının yivleri daha düzgün olsun diye sıva harcı işle düzeltilmiştir. Birçok sütunda bu düzeltmeler görülmektedir (Fig. 41 ve 42). Fig. 42'da daha az harç ile birleştirilmiş bir blokta taneler ve harç ilişkisi çok daha iyi görülmektedir. Bu sütun tamburlarının da üzeri harçla sıvanmıştır.

Anıt mezarın deniz tarafında serbest haldeki bir sütun tamburu harç ve tane ilişkisi çok iyi bir

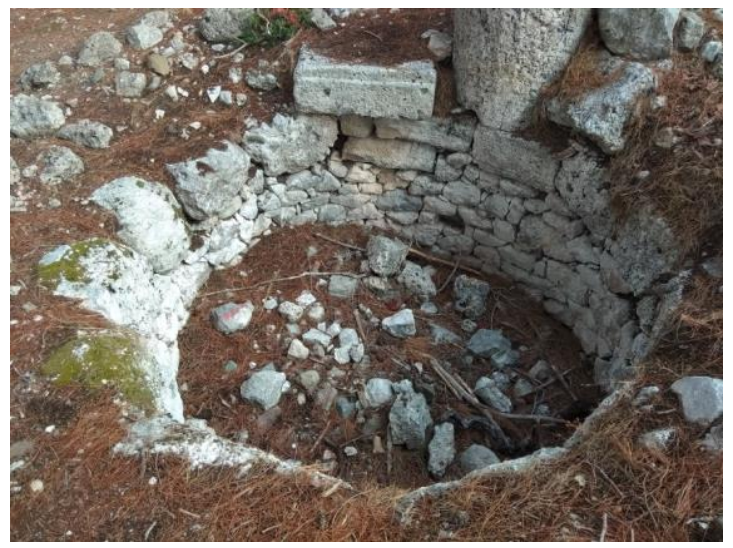

Fig. 45. Anıt Mezar Batısında Kireç Kuyusu (Yaklaşık 2 m çapında) şekilde izlenebilmektedir (Fig. 42).

Hamamın batı tarafında bazı blok ve sütunlar duvar şeklinde dizilmiştir. Fig. 43'de alttaki yapay sütün üzerinde traverten breşinden yapılmış iki adet devşirme blok harçsız bir şekilde üst üste konulmuştur. Burada yapay sütün ile traverten breşi yapıları çok açık olarak incelenebilmektedir. Üstteki traverten breşlerinde özellikle boşluk kesimlerinde karbonatlı suyun dolaşması sırasında oluşan izler görülebilmektedir (Fig. 44).

Anıt mezarın yakınında bulunan yuvarlak bir kuyu araştırmacılar tarafından kireç kuyusu olarak değerlendirilmiştir (Fig. 45). Yapay blok ve sütunların kireç yapımından artan breş veya kireçtaşı parçalarının kireç harcıyla birleştirilmesiyle yapıldığı söylenebilir.

MÖ 90 ile 20 yılları arasında yaşamış Romalı ünlü mimar Vitruvius'un mimarlık üzerine derlediği kitabında bu tür oluşumlara benzer imalatlara değinilmiştir (Vit. V. 5). Kireç kuyularında ısıtılan kireçtaşı parçaları kireç harcıyla ıslatıldığında oldukça sağlam birleşme olduğunu belirtmektedir. Kireçtaşı kısmen ısıııldığında $\mathrm{CO}_{2}$ in bir kısmını kaybetmektedir. Bu sırada hacmen aynı kalmakla birlikte ağırlığının yaklaşık \% 30 u azalmaktadır. Sıcak haldeki bu kireçtaşı parçaları kireç harcıyla birleştiğinde oldukça sağlam duvarlar yapıldığını anlatmaktadır. Anıt mezar ve etrafındaki bu blok ve sütunların denize bu kadar yakın olmasına rağmen oldukça iyi durumda olmaları belki de bu özellikten olabilir.

\section{Traverten Breşlerinin Ocağı}

Öner $(2018,354)$ Phaselis Küçük Hamam ve latrina yapı taşları ile ilgili yayınında traverten breşlerinin akropolis'in konuşlandırıldı̆̆ tepenin üst kesimleri ve Doğu Nekropolis alanının kuzeyinden başlayıp Tahtalı Dağı'na kadar olan alanda geniş bir alanda yayııımda olduğu belirtilmiştir (Fig. 46). Ayrıca Kuzey Limanı'ndan bakıldığında ocak olması muhtemel bir alanda ocağın burası olabileceği düşünülmüştür.

2019 çalışmalarında bu bölgenin doğusunda yer alan podyumlu tapınak alanının kazı çalışmalarında Kemer-Tekirova Karayolu'nun alt seviyelerinde de ocak olabilecek şekilde kazılmış olarak görülen alanlardan inen devasa bloklar dikkat çekmiştir. Blokların bazı kenarlarının oldukça düzgün olması bunların ocaktan erozyonla kaymış bloklar olduğu izlenimini uyandırmıştır (Fig. 47).

Bunun üzerine podyumlu tapınaktan kentin Hellenistik Akropolis'i ve doğu kapısı yönündeki tetkikler yapılmıştır. Yapılan araştırmalarda taş ocağı olabilecek alanlar gözlemlemişlerdir.

Özellikle podyumlu Hellenistik tapınağın hemen üstünden başlayan alanın üretim yeri olabileceği düşünülmektedir (Fig. 48 ). 


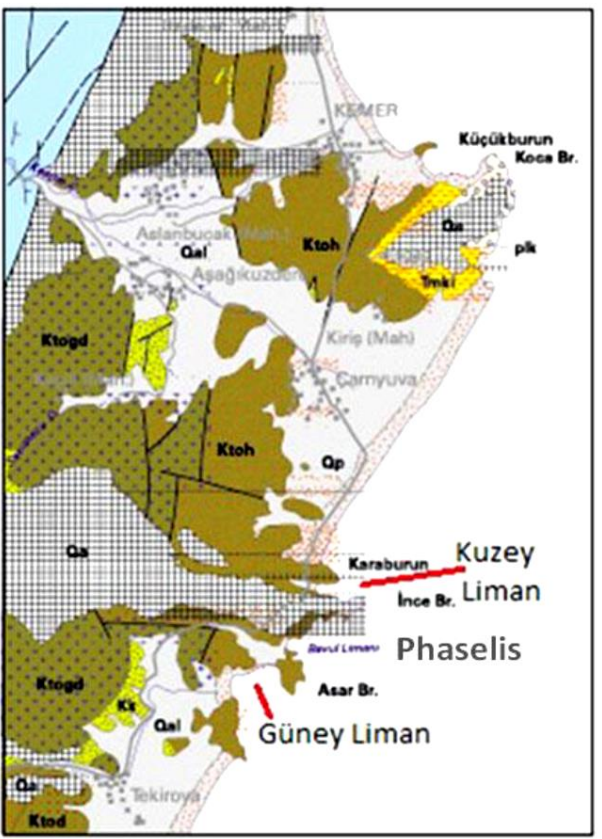

Fig. 47. Tapınak alanına Erozyonla Kayan
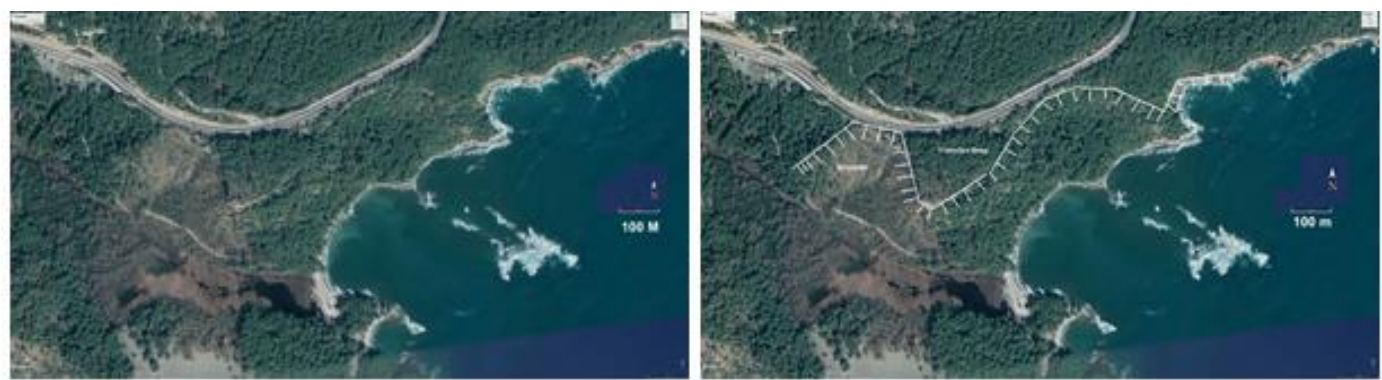

\section{Açıklamalar}

Oym Yamas molozu vo binkinst korisi

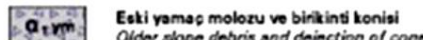

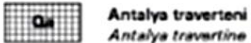

Inki Kiris formation: Calcarenitn ciome fimestone, claystone

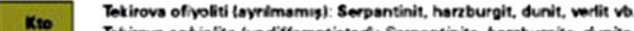
Takirova ophiogito lundifferentiotedi: Sarpentinite, harzburgite, dunith wherbitu ot Cabro ve diyabazlar (eyrimama) Gabbre and dobases inndiftorontiated Dunit: Dunit, cerpantinkapmig dunit, dunit harzburgit ardalanm Dunite: Dunite sevpentinised dunite, alternstion of dunite-harzburgite Marzburgit: Lenolitik hanburgt, mesit harnburght, banth henburgt vit.

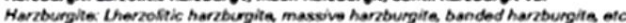
Thatedap formasyonu: Norit h reçtas"

Tanmlanmamis fay, veri yatlogik tanimlonmamis fay Undefined foult, appraximgtail located undefined faut Olasa tay

\begin{tabular}{|c|c|}
\hline Oal & 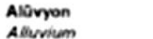 \\
\hline or & $\begin{array}{l}\text { Kumullar } \\
\text { Dunos }\end{array}$ \\
\hline 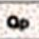 & $\begin{array}{l}\text { Plaj olupuaton } \\
\text { Beach sediments }\end{array}$ \\
\hline day & $\begin{array}{l}\text { Aluryon yolpocesi } \\
\text { Alifwig//gn }\end{array}$ \\
\hline
\end{tabular}

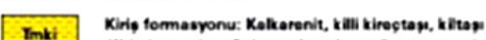

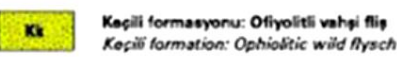

Fig. 46. Phaselis Antik Kenti ve Çevresinin Jeolojik Haritası (Öner 2018, 353)

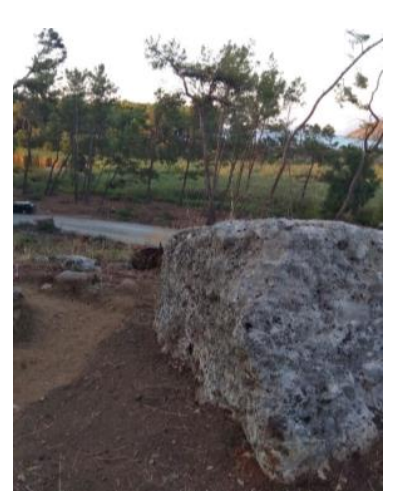

Traverten Breş Kütleler

Fig. 48. Phaselis Antik Kenti Kuzeyindeki Yapı taşı Ocak Alanı 


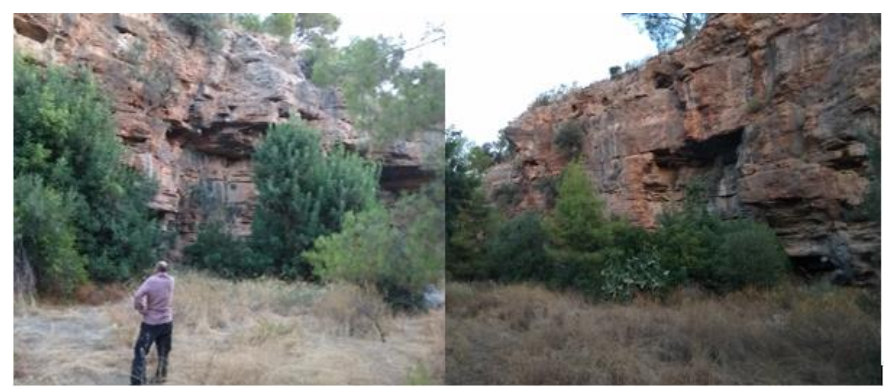

Fig. 50. Yapı Taşı Üretim Ocak Alanı

Fig. 48'de Phaselis'in uydu resmi gözlenmektedir. Fig. 48'de sağ taraftaki resimde set şeklinde görülen sınırlar çizilmiştir. Fig. 48'de sol resimde serpantin işaretli alana bakıldığında bu alanın 2019 daki hortum felaketinden sonra Orman Genel Müdürlüğü yıkılan ağaçları temizlemesi ile daha iyi bir şeklide açığa çıkmıştır. Serpantin kayası üzerindeki traverten breşlerinin alınması ile bu alanda erozyon artmış ve ocaktaki bloklar eğim aşağıya yola kadar inmişlerdir. Bu kesimin hemen altındaki bataklık/göl alanının da eriyen serpantin malzeme ile dolduğu düşünülmektedir. Fig. 49'daki uydu fotoğrafında ocak alanı ve gölün ilişkisi görülmektedir.

Bu alan şehir surlarına kadar incelendiğinde pek çok ayna oluşturulduğu (madencilikte üretim yapılan basamakların ön yüzleri "ayna" olarak anılmaktadır (Fig. 50). Bu alan yakından incelendiğinde blok üretim izleri çok kolay görülebilmektedir (Fig. 51 ).
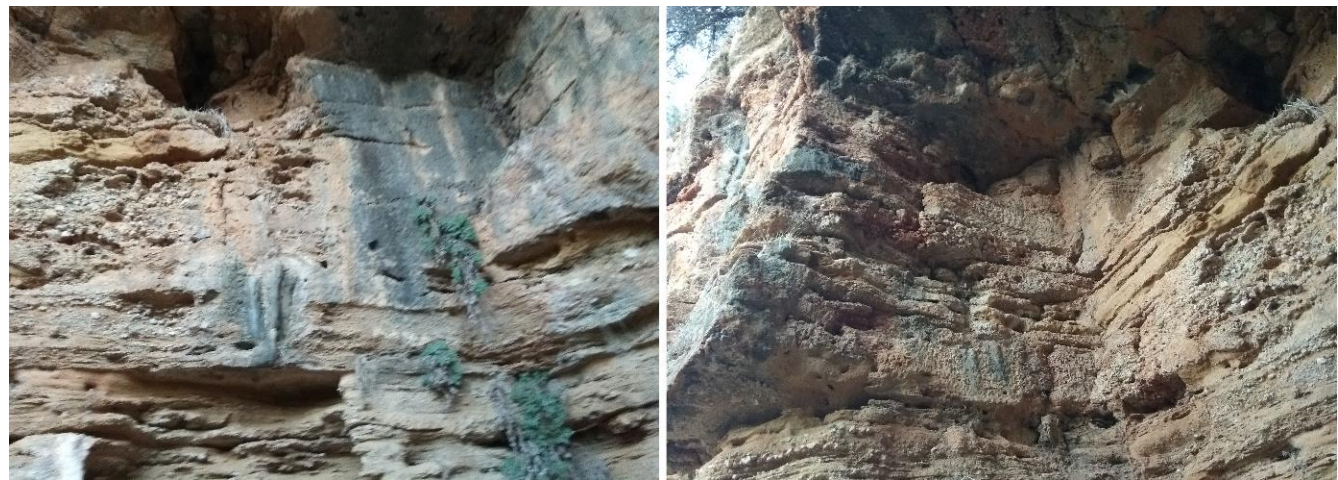

Fig. 51. Ocak Alanında Blok Alınmış Aynalar

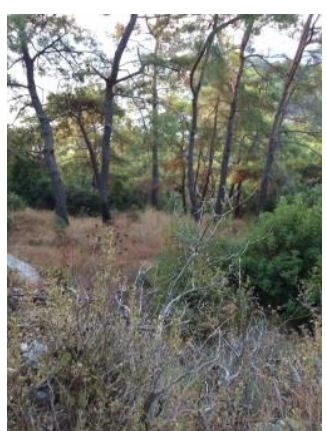

Fig. 52. Ocak Alanı Güneyindeki Alt Kademe

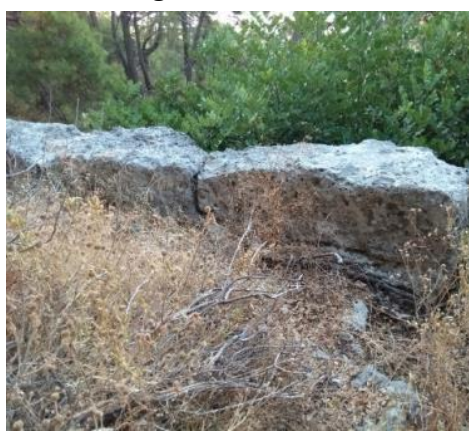

Fig. 53. Phaselis Giriş Kapısı Sur Duvarları

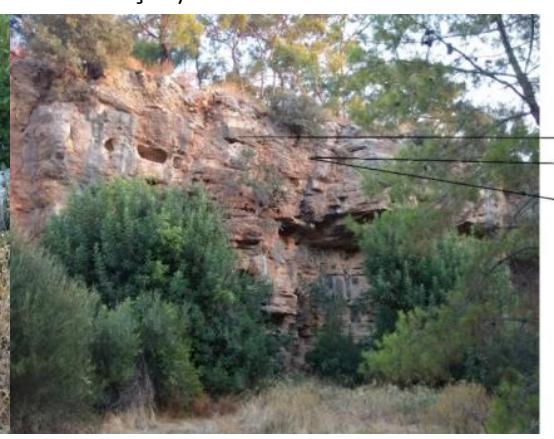

Fig. 54 Yapı taşı Ocağı Aynasında Yapısal Değişimler 


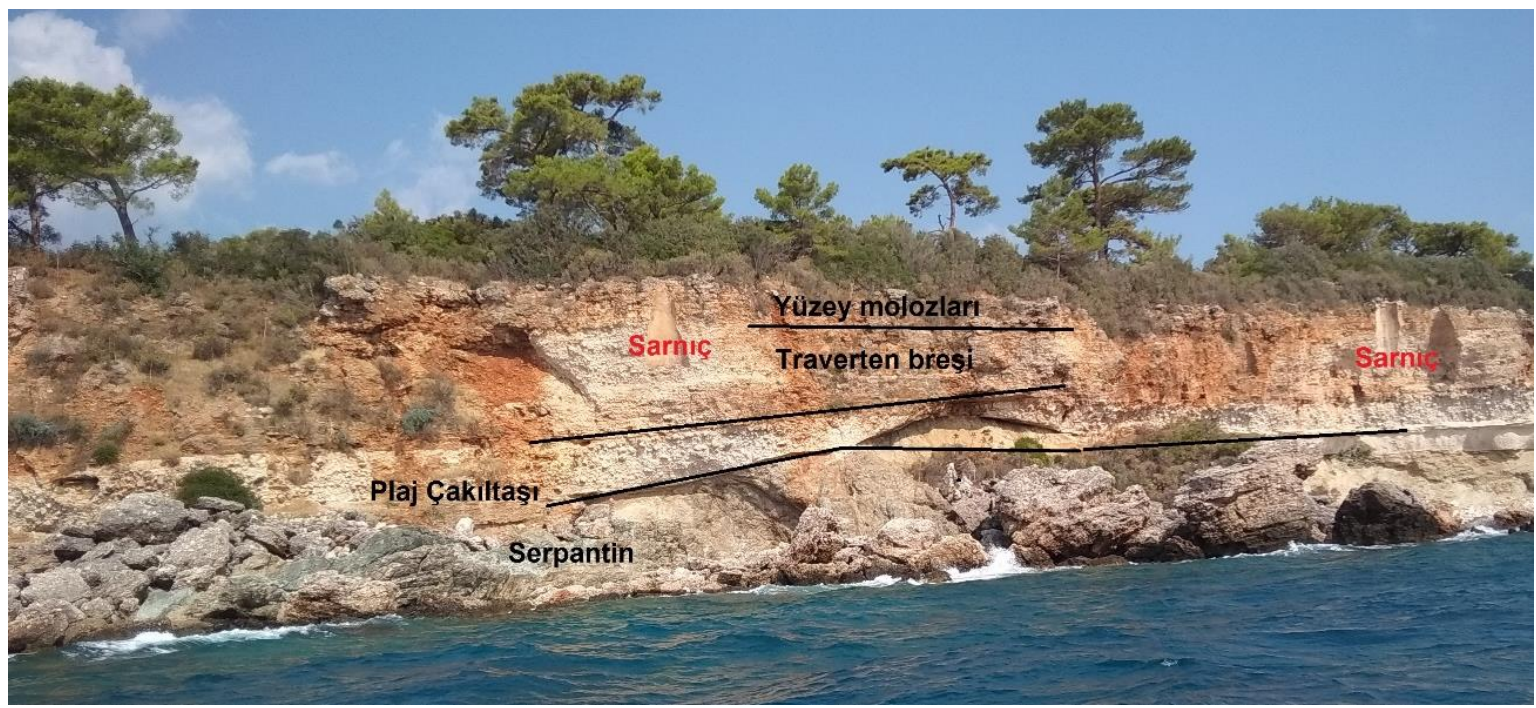

Fig. 55. Hellenistik Akropolis'in Güneydogu Yamaçları

Bu alandan itibaren aynaya dik yönde iki kademe üretim yapıldığı tahmin edilmektedir (Fig. 52 ). Üretilen alanın en az 50 m olduğu Google Earth görüntüsünden ölçülmüştür. Bu aynanın yaklaşık doğu batı yönünde $400 \mathrm{~m}$ ye kadar devam ettiği ölçülmüştür. Kalınlık yaklaşık $10 \mathrm{~m}$ olduğu düşünüldüğünde (Fig. 50) bu alanda yaklaşık "400×50×10 = $200.000 \mathrm{~m}^{3}$ taş alınabileceği hesaplanmıştır.

Yapı taşı olarak kullanılan ortalama blokların $50 \times 30 \times 25 \mathrm{~cm}\left(0,03 \mathrm{~m}^{3}\right)$ ölçülerinde olduğu düşünülürse;

Bu alandan 200.000/0,03= 6.666.666 blok üretebilme kapasitesi vardır. Yaklaşık 6-7 milyon taş bloğunu bu alandan alınabilecektir. Phaselis yapılaşmasında kullanılan düzgün bloklar düşünüldüğünde taşların kaynağı olarak bu alan akla yatkın görülmektedir. Illk üretilen alanın duvar örülerek şehre giriş yolu (Fig. 53) yapıldığı görülmüştür. Öner (2018 sayfa 357) de Phaselis kentinde kullanılan traverten breş bloklarında gözlenen bozunmalar anlatılmaktadır. Traverten bloklarının matriks olarak bilinen parça birleştiren hamur malzemesinin cinsine göre bozunmalar değişmekte olduğu belirtilmiştir. Öner (2018 sayfa 358)'e göre kil matriksle oluşan traverten breşleri doğal şartlarda aşınarak bozunduğu ve ara malzemenin erimesi ile tanelerde de boşalmalara neden olmaktadır. Karbonat çimentolu breşler ise zamanla daha sağlamlaşarak daha sağlam hale geçmektedir. Fig. 54'de yapı taşı ocağının aynasında bu seviyeler açıkça görülmektedir. Taşların üretildiği dönemlerde bu özelliklere çok dikkat edilmediği görülmüştür.

Hellenistik Akropolis'in üstü de traverten breşlerinden oluştuğu için de burada da bir yapı taşı ocağı olup olmadığı araştııılmıştır. Akropolis deniz tarafından incelenmiştir. Akropolis kesiminde de yerleşimin altı bu tür traverten breşi, travertenler ve plaj seviyesi çakıltaşlarından oluşmuştur (Fig. 55). Deniz seviyesi serpantine geçmektedir.

\section{Sonuçlar ve Değerlendirmeler}

\subsection{Sonuçlar}

- Phaselis'in ilk yapılaşmasında kullanılan taşların (akropolis, podyumlu Hellenistik tapınak, Doğu Nekropolis'in girişindeki anıt mezar, kent surları, hamamlar, latrina, agoralar ve lahitler) traverten breşinden düzgün bloklar olarak üretildiği belirlenmiştir.

- Daha sonraki evrelerde ilk olarak çöken veya işlevini yitirmiş binaların blokları 
kullanılmıştır. Bu bloklarla örülen duvarlarında kısmen düzenli olduğu görülmüştür.

- Bundan sonraki evre ve/veya evrelerde dere taşları traverten blok parçaları, Hadrianus döneminde (MS 117-138) eklektik olarak gelen mermer, Limyra mermeri vb. tüm malzemenin kendileri veya kırıkları düzensiz olarak kullanılmıştır.

- Geç Antikçağ’da yapı duvarlarının bu kadar düzensiz olmasına rağmen halen ayakta olması bağlayıcı harç olarak kullandıkları kireç harcına güvenmeleri olarak yorumlanmıştır.

- Bu dönemde kireç üretilirken kullanılan kırık malzemeleri değerlendirmek için sınırlı sayıda sütun ve yapı taşı üretildiği tahmin edilmektedir. Bu malzemelerin kireç kuyusunun yanında bulunmaları ve kalıp izleri bu kanıyı güçlendirmektedir.

\subsection{Değerlendirme}

Önümüzdeki dönemlerde Phaselis antik kenti ve çevresinin 1/10.000 ölçekli bir jeolojik haritasının yapılaması gerekecektir. Bu jeolojik harita üzerine ocaklar, bilinen tüm yapı unsurları (eski ve yeni duvar ayrımı yapılarak) işlenmesi antik kentin gelişimi ve jeolojik olaylar konusunda daha detaylı yorumlar yapılmasına imkân verecektir.

Yapı taşları ve üretim malzemeleri (tuğla, kiremitler, değişik yaştaki doğal kayaçlar) üzerinde izotop jeokimyası ve jeokrolojik yaş analizlerinin yapılması için imkânlar araştırılacaktır. Bu sayede örneğin hamamların en son yakılma yaşları, yapma olarak söylediğimiz sütunların kökenleri, seramik ve tuğla malzemelerinin kil kaynakları vb. bilgiler aydınlatılabilecektir.

\section{BIBBLIYOGRAFYA}

Arslan - Tüner Önen 2019 M. Arslan - N. Tüner Önen, “Phaselis Kenti'nde 2019 Yılında Gerçekleştirilen Yüzey Araştırmaları ve Kazı Çalışmaları". Phaselis V (2019) 425-463.

Erol 2008

A. Erol, Finike Yöresi (Batı Toroslar) Limyra Mermerlerinin Jeolojisi ve Ekonomik Potansiyeli. Yayınlanmamış Yüksek Lisans Tezi, Dokuz Eylül Üniversitesi. İzmir 2008.

Işık 2019

V. Işık, "Kayrak Taşı Adlanması, Jeolojisi ve Kullanım Alanlarına Genel Bakış". Mavi Gezegen Dergisi 26 (2019) 54-63.

Moore et al. 1952 R. C. Moore, C. G. Lalicker \& A. G. Fischer, Invertebrate Fossils. McGraw-Hill Book Company, New York 1952.

Öner 2018 F. Öner, "Phaselis Antik Kenti Küçük Hamam'ı ve Latrina'sında Kullanılan Yapı taşları ve Bu Yapı taşların Bozuşmaları". Phaselis IV (2018) 351-360.

Şenel 1980

M. Şenel, Teke Torosları Güneydoğusunun Jeolojisi Finike-Kumluca-Kemer (Antalya). MTA Derleme No: 6874, 1980.

Şenel et al. 1981 M. Şenel, M. Serdaroğlu, R. Kengil, M. Ünverdi \& M. Z. Gözler, "Teke Torosları Güneydoğusunun Jeolojisi”. MTA Dergisi 95-96 (1980-1981) 13-43. 